\title{
The Typology of Socially Disadvantaged Families
}

\subsection{INTRODUCTION}

The previous two chapters looked at some of the core aspects of our longitudinal study, as observed from the children's development, their media repertoires and the different contexts of socialisation that play a role in their lives, and they considered the mediation strategies that we identified from our panel.

The study's data shows one thing very clearly: the children in the sample grew up in very dynamic and heterogeneous contexts. Each family displayed patterns of factors unique to it and shaping the everyday life experiences of all its members, and especially the children's. The specific interplay of individual key factors in a family influenced the socialisation of the children. The influence of different factors varied for each family: for some, one particular financial situation was more challenging than it was for others; different families coped with available resources in very different ways, for some, the climate between family members put a strain on their everyday lives and weighed on them more heavily than the financial deprivation.

Our discovery of the similarities in, and differences between, the respective family lives (doing family) of our subjects was the starting point for developing a typology of the families in the sample. We followed Kluge's (2000) approach to the construction of qualitative types (see Chapter 4 ), beginning by identifying the main dimensions available

(C) The Author(s) 2019

I. Paus-Hasebrink et al., Social Inequality, Childhood and the Media, Transforming Communications - Studies in Cross-Media Research, https://doi.org/10.1007/978-3-030-02653-0_8 
for characterising the families. Building on the results of the first four waves, we identified the following: the socio-economic situation of the family (e.g., their finances, employment and their standard of living), the socio-emotional climate (e.g., the relationship between family members, the observable conduct of family members with regard to each other and so on) and the identifiable coping strategies (how each family was able to deal with everyday challenges resulting from social disadvantage).

We first developed our typology in 2014 (see Paus-Hasebrink \& Kulterer, 2014, p. 239), after four waves of data collection $(2005,2007$, $2010,2012)$. On the study's completion, after two more waves of data collection $(2014,2016)$, we revised and improved our typology in 2017 (see Fig. 8.1). The dimensions used for the identification and description of the types remained largely the same, but were in some cases renamed to provide a better understanding of their meaning. Due to various changes that the families themselves underwent between both waves, some families were moved from one type to another (e.g., because their financial situation had improved or because the family climate became more relaxed, or because their situation took a turn for the worse) and ultimately, one of the previous five types was merged with another already existing one (Type 1 and Type 2) since the differentiation

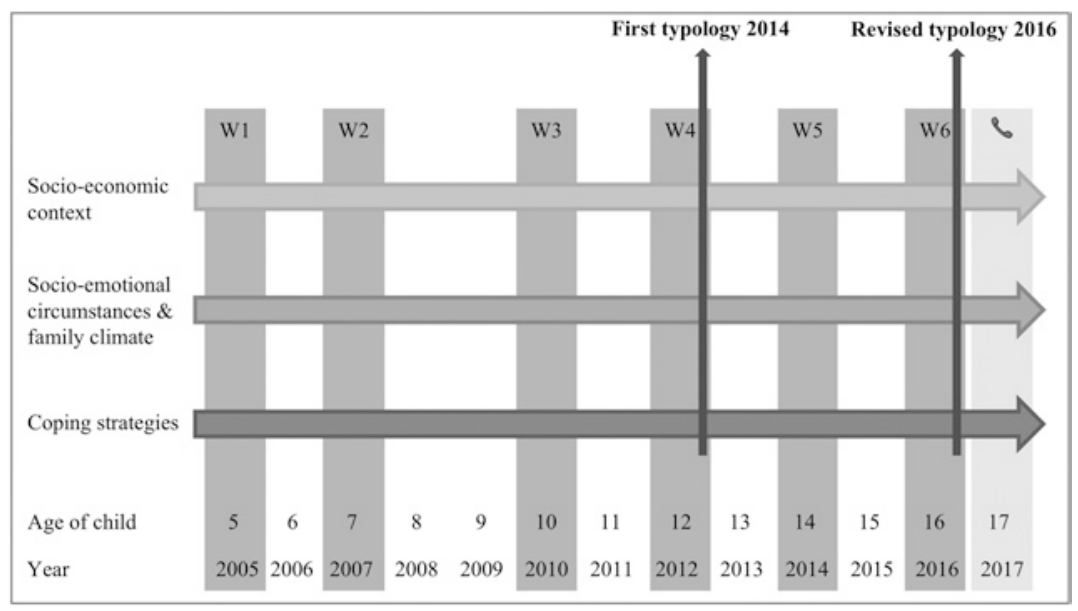

Fig. 8.1 First typology 2014 and revised typology 2016 
between both had become less distinct as the remaining families of previous Type 2 had experienced an aggravation of their problems. These changes resulted in four family types, as shown in the matrix below (see Fig. 8.2). This shows how the various dimensions combine to illustrate the different family types.

The following portrayal of the family types views each family as a whole, together with its development over the years, but it focuses on the most recent data from the last two waves of data collection. At the core of the analysis and description of the types are the three analytical concepts: options for action, outlines for action and competences for action (see Chapter 3). Our portrayal of the types aims at highlighting the interplay of these three concepts against the background of the challenges confronting parents and children-the life tasks confronting the parents and developmental tasks (Havighurst, 1972) confronting the children-and their strategies of socialisation and of parenting, as well as their accompanying media use. We stress that these concepts were not identified independently and then analysed with regard to how they relate to each other, as the families' individual natures and the nature of their relationships are much more complicated. Not all factors can be defined by simply looking at their objective manifestations, but they

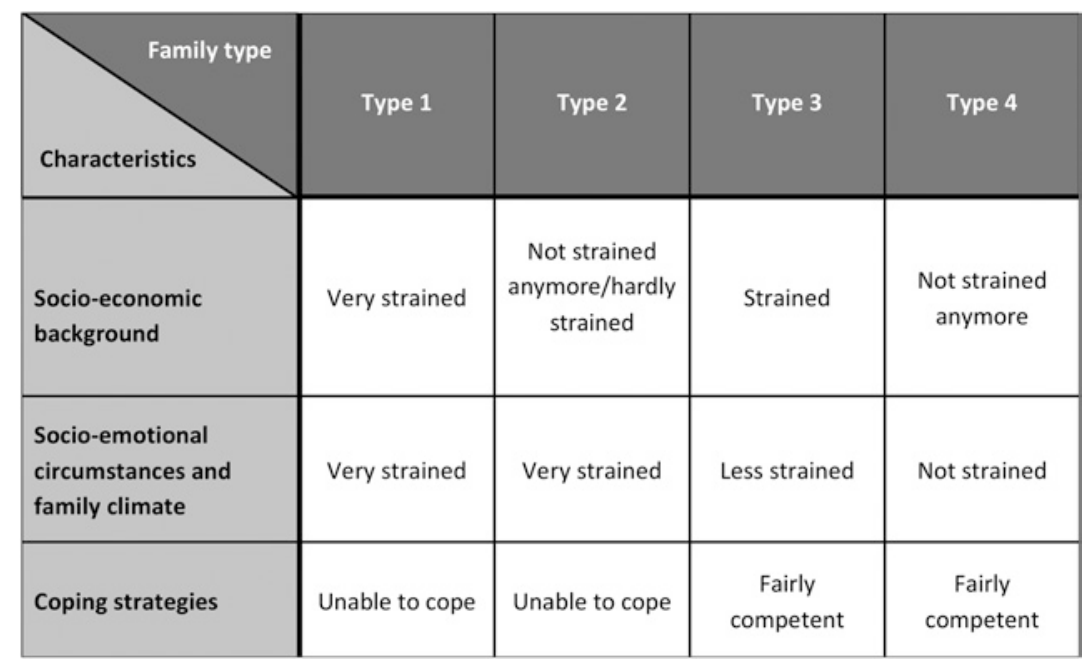

Fig. 8.2 Four family types-typology 2016 
also have to be analysed for each individual's subjective perception of their situation-very similar circumstances on the objective level do not automatically mean the same thing for different individuals and have the same consequences for them.

To demonstrate what is meant by that, we have chosen one case to describe in more detail. It represents each of the family types and provides a deeper insight into lifeworld of the respective child and its family, and displays with the different combinations of characteristics, and the individual interplay of these characteristics designating the family as belonging to this type. This form of in-depth analysis allows for a better understanding of the processes of socialisation the children undergo throughout the years and what role media play in this context.

The other families within the same type will be dealt with in less detail, while still addressing the relevant issues. ${ }^{1}$

\subsection{The Families of Type 1}

Massive Socio-Economic Problems as the Result of Multiple Forms of Deprivation: The Families Overwhelmed in All Respects. (Landinger, Oblinger, Fein, Öllinger)

The families of Type 1 are either large families (with more than five children $^{2}$ ) or single-parent families. All of them struggled with everyday life challenges throughout the duration of the study, so that their respective circumstances remained, comparatively, the most critical right up to the end of the research.

These families experienced deprivation on various levels: on the one hand, they experienced massive socio-economic deprivation while, on the other hand, psychological and physical problems additionally burdened the family situation, often leading to parental unemployment or contributing to developmental problems in the children. All of these families continued to suffer under their situation right up to the end of the study.

A precarious financial situation was often mirrored in the living situations. Either the families lived in rather small and/or old apartments or older houses, some in remote, rural areas with weak infrastructure where rents are lower and job opportunities scarce, or in deprived and less popular areas in cities. For the adolescents, this meant fewer choices over schools, job training and education programmes, thus limiting their 
perspectives for the future, as well as often restricting their latitude for spending time outside of the family home.

At the end of the study it became clear that the parents of these families would probably not be able to improve their situation because they were overburdened by the challenges posed by the limited options for actions. At least one of the children from the Type 1 families, Manfred Oblinger, found a promising future perspective in training to become an IT technician. The future of Timo Landinger and Olivia Fein, who were both participating in special programmes to help unemployed teenagers integrate into the job market, was still rather unclear at the end of the study. Viktoria Öllinger had aspirations to finish school, maybe go abroad, and then later find a job in public service, but it still remained to be seen whether her endeavours would be successful.

With regard to the parenting strategies of the Type 1 families, we can say that most of them had a sense of responsibility for the development of their children and for their opportunities in life, but some of them, like the Fein and Landinger families, clearly saw their children as an additional burden and maintained a rather distanced relationship with them. In this context, the media were seen as welcome "tranquillisers", especially in the early years, and as ways to keep the children occupied without too much effort. They often reflected on this issue, but it was clear that the gap between the parents' ideals, between their outlines for actions ("wanting") and their actual competences for actions (actually "doing"), was often too big. This became evident in many aspects of the way they lived and, in the ways, they dealt with their life tasks, with parenting and media education figuring among these.

\subsubsection{The Case of Timo Landinger and His Family}

\subsubsection{Situation and Climate of Relationships Within the Family}

Timo (17 years old in 2016) was the youngest child in a large family that suffered from severe deprivation on multiple levels throughout the study. The family consisted of Mr. Landinger and his wife (between the last two interview waves, they got married after having a relationship for 28 years) and six children; Mr. Landinger was the biological father of the four youngest siblings. The family situation had been marked by instability, conflict and violence throughout the years. 
Timo's situation within this family was especially depressing, as, from an outside perspective, his world seemed rather constrained and bleak. The crisis in the family escalated at one point between the first and second waves of data collection, driving Timo's mother and the younger children into a women's shelter. The parents reconciled and moved to another county, but the situation did not improve for Timo. He remained psychologically impaired, and his needs were mostly neglected by his parents, who were initially too preoccupied with financial issues, and later with health-related ones (psychological as well as physical). Both parents were permanently unemployed and did not seem eager to actually find a job but tried to get as much welfare money as possible. Through online research, Mr. Landinger diagnosed himself with 62 diseases and sought to have them acknowledged in order to receive more money.

The housing situation mirrored the precarious financial situation of the family. At first, it was living in a crowded apartment and later moved into a house in a remote, rural region of Austria-we could not ascertain how the family was able to finance this purchase. The house needed renovating and the family put some effort into improving its state, with some success. The interior of the house was messy and anything but clean. The living area was crammed with objects, and everything smelled of stale cigarette smoke (both parents were heavy smokers). The exception was Timo's room, where he seemed to try to bring some feeling of order and control into his life by keeping it tidy.

The adjacent building on the family's property remained rather desolate, and its function was unclear right up to the end of our study. It was used for storage, but also for hobbies, and it included a bathtub and warm running water.

All the problems burdening the parents during the study meant that their constant struggle impinged directly on the children, with violence often used as the parents' main response to conflicts. All this contributed to rather cold relationships, with hardly any affection between the family members, and Timo clearly suffered from this lack of warmth and affection, stating in one of the interviews that he had the feeling that no one liked him, not even the cat.

The climate within the family was, furthermore, marked by the very dominant father, who seemed to derive his self-esteem solely from his sway over the family. In order to maintain his dominant position, he used psychological humiliation, as well as physical punishment. Mr. Landinger 
expected subordination from the other family members and did not hesitate to enforce his will, although he denied any use of violence. His son's statements, and his wife's behaviour clearly suggested otherwise. Mrs. Landinger was clearly marked by her relationship to her husband, as she seemed timid and jumpy in his presence and had only very limited options for actions. She also seemed to be psychologically impaired and was in therapy in a special facility during the last years of the study. She seemed to have prematurely aged and apparently had no significant influence on the family's life.

Timo's cognitive and emotional-affective development had suffered under the multiple problems the family experienced, as well as from the lack of support within it. He was diagnosed with ADHD and other mental deficits and needed special care, which could not be provided by his parents. He did not receive adequate treatment and help, despite being home-schooled for some time, was then admitted to a psychiatric clinic after a situation in primary school escalated and was finally placed in a specialised socio-pedagogical living facility and school where he lived during the week. He completed his years of compulsory schooling in this facility and moved back into his parents' house permanently between our fifth and sixth waves. He showed progress in his development during the time he spent in the facility, did not have to rely on a number of different medications anymore and clearly profited from the stable routine, the therapeutic exercises and strict guidelines for media use and from the contact with other children of his age. However, returning home landed him back in his confined micro-cosmos, where he spent his days with computer games and working with a special programme aimed at enhancing his chances for job training but without producing any results by the end of the study.

Timo remained slow to develop and had severe problems with writing, as his network map shows (see Fig. 8.3). ${ }^{3}$

It cost Timo no little effort to produce the map, which is full of mistakes, like the "E" used instead of a " 3 " in "PS3" (PlayStation 3), as well as spelling mistakes.

Mr. Landinger openly stated that he wanted to undo what the school/facility taught his son, so that Timo would be socialised as Mr. Landinger saw fit. Timo had no friends and no social contacts outside of the family anymore. He had one friend, but Timo's father saw him as a threat to his dominance in the family and so drove him away. Violence and demonstrations of power were seemingly the only competences for action that Mr. Landinger knew. 

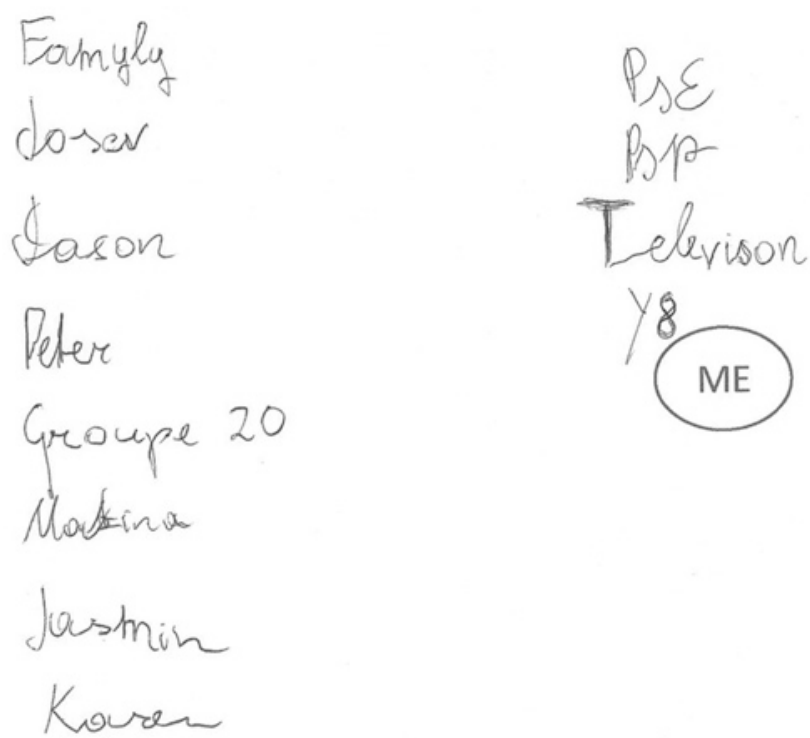

Fig. 8.3 Network map by Timo Landinger in 2016 (Tracing based on the original, translated and anonymised by the authors)

Much like his mother, Timo appeared to have resigned himself to his fate, as he made no attempt to break free of the situation or to change anything. His options were very limited, and he simply lacked the perspective and the outlines for actions, as well as the competences, to see any perspective beyond his world. Timo's father actively restricted his son's options-although they were already limited due to the family's situation-probably because he feared outside interference threatening his dominant position. Timo was apparently very intimidated and said at one point that he would like to hit his father back, but conceded that he could not, as his father was, after all, just that.

\subsubsection{Media}

Against this background, the media played a crucial role in Timo's life from early childhood on. They were his constant companions when he was, more or less, left alone by his family. The Landingers did not pursue much in the way of leisure time activities and spent most of their 
time confined to their home. When Timo was older and living in the assisted-living facility during the week, he often expressed interest in pursuing activities like visiting a farm or, when he was at home, learning how to make bread, but his parents always discouraged him, arguing that the weekdays were so exhausting due to commuting to therapy and to Timo's school, that the family needed time to rest on weekends. So, Timo was left to pursue his media consumption as a way of keeping him occupied.

Since the beginning of the study, the media had served as a platform to engage in fantasies of power, which helped Timo to cope with the lack of power he experienced in everyday life. In our second wave, Timo declared he wanted to be a Pokémon, so that he could scare his family and the children in school.

First television, and later computer games, provided an opportunity to experience some form of self-efficacy. Fighting, proving himself and a sense of achievement were his primary motives for media use, especially with regard to computer games. His fascination with violent (and age-inappropriate) video games and media content, especially with anything related to the topics of war, death and violence, persisted over the entire period.

The media not only became the primary leisure time activity for Timo, but they were also a way to cope with his aggression and give his everyday routine a structure. His parents did not restrict this media use in any significant ways, except for prohibiting the use of the internet, because they did not think that Timo had the ability to use it. We consider it probable that their real motivation was that his access to the internet would mean they would have to try to exercise some sort of control and mediation in order to avoid risky/harmful situations. Accordingly, Timo had a mobile phone from 2014 onwards, but it was an obsolete model with no internet connection.

Timo had free access to different game consoles (PlayStation 2 and 3 as well as a PSP) and a large number of video games. The two pictures ${ }^{4}$ that Timo took of his favourite place in his room during the last panel wave show 33 video games (most of all fighting games), which represented only part of his game collection.

Mr. Landinger said in 2012 that video games were his son's world, one that he did not want to deprive him off, since, in his opinion, Timo found his own identity and more self-esteem in playing these games, even if he lost a hundred times. At this point, it has to be said that Timo 
was not actually good at playing these games. On a couple of occasions, he played games during or after the interviews, providing the interviewers an insight into his limited abilities to process the action and to master the game challenges. The picture of his favourite media place in his room from 2014 shows the screen of his television displaying the menu of a game he was about to play also during the interview.

In 2016, Timo himself claimed to be "addicted" to video games. On weekends he often seemed to be playing games for 12 hours straight, and during the week it was the first thing he did after coming home from his job training-something that both his own statements and his parents' statements underline. In his last interview, Timo said: "I only dream about games, games, games". Timo's parents emphasised the role that video games play in calming Timo down. In 2016, the parents claimed that, if it were not for the games, there would have been no respite from the stress with their son.

The parents' own range of media was not much broader either. The most important medium in the house was the TV. Mr. Landinger was always eager to emphasise his dedication to information programmeshe was definitely interested in various subjects and had a vast factual knowledge, but tended to conflate topics and arguments, leaving his own utterances hard to understand for outsiders. In general, it appeared that the entertainment programmes of various private broadcasting stations dominated the family's media use.

Mr. Landinger used the computer and the internet from time to time to do research or to file papers for authorities online. Books were almost non-existent in the household, and the family did not take a newspaper, but only occasionally read free local papers, while Mrs. Landinger read magazines mostly related to hobbies, such as crocheting.

Throughout the study, Mr. and Mrs. Landinger tended to a positive opinion of the media. They valued them highly for their relaxing effect and for the opportunity they provided to recover from a stressful everyday life, but hardly ever evinced any form of critical analysis. In some interviews, these parents indicated some awareness of popular public discourses on the risks of media use, especially the risks from online exposure or those associated with violent content and its effect on a child's psyche. However, their own approach to their son's media education and their rules for media usage indicate that these statements most likely deferred to social desirability. Consequently, their uncritical approach to the media precluded any form of media literacy. 


\subsubsection{Parenting and Role of Socialisation Contexts}

The overall approach to parenting in the Landinger family can only be described as non-existent or, at least, amorphous and inconsistent. The parents displayed a mixture of the mediation practices we identified as unmethodical restriction and arbitrary control/exploitation of dominance (see Chapter 7). Throughout the years, there were few clear rules, and those there were (e.g., that Timo was not allowed to use the internet), were mostly not explained to him, let alone consequently enforced. Rather than monitoring Timo's media usage and discussing it with him, the parents set arbitrary restrictions. In order to assert his ideas of proper behaviour, Mr. Landinger did not shy away from physical violence, which, as he argued, was preferable to psychological violence, something he viewed as torture. When Timo was still living in the socio-pedagogical facility, his parents had even refused to do any kind of parenting at all, because they had felt that their son had to follow too many rules in the facility anyway, so they wanted to leave him alone on the weekends to relax.

All in all, it became clear over the years that Timo's parents were unwilling to deal with their responsibilities as parents in general, and with issues of media literacy in particular. As our study indicates, their parenting style-if that is even the right word to use-builds on unmethodical restrictions rather than mediation and on enforcing their ideas of dominance through violence.

For a short period, Timo was able to experience other forms a socialisation from outside of his family, which helped to widen his perspective, only to be reduced again after moving back home to his family, where his father limited his contact with people outside of the family to a bare minimum.

In the light of all this, Timo's future remained unclear. When the study ended, he still had no job prospects and hardly any friends and social contacts. During the final phone call marking the end of the study, Timo appeared apathetic and devoid of any emotion.

\subsubsection{Other Families of Type 1}

\subsubsection{The Oblinger Family}

This family consisted of Mr. and Mrs. Oblinger and their six children. The oldest three stem from Mrs. Oblinger's first marriage and had 
already moved out by the time the study began. However, they continued to live close-by, except for the oldest son, who lived in a neighbouring region. Manfred was the oldest of the remaining siblings and impressed as highly talented.

Throughout the study, this family was overwhelmed, both by their poor financial situation and by multiple strokes of fate, especially regarding the parents' health.

The family lives in a fairly remote and mountainous area, with poor access to public transport. They moved there, shortly before the study began, to acquire an affordable home for the large family. Mr. Oblinger had to give up his job, because there were no openings for a technical draftsman in this region, and he became a cook instead-the region's tourism creates a demand for this occupation. Although prospects in the area were limited, especially with regard to education and jobs, and although the family had to sacrifice a lot when they moved there, they remained content with their housing situation throughout the study.

Mrs. Oblinger was never employed during the study, and during its last years she suffered a stroke, becoming unable to work due to the ensuing depression. Before our sixth wave, her husband suffered a knee injury coming home from work at a skiing hut. An operation resulted in a chronic infection, rendering him also unable to work and later leading to depression. So the family had to struggle with even fewer resources and was living on the bare minimum of social welfare. This situation put a strain on the climate within the family and became their dominant concern.

As a child, Manfred experienced this growing lack of resources from an early age, and it always preoccupied him. He always talked about how he wanted to earn a lot of money when he was a grown-up and that he wanted to save it. The little money he received, he hid away without spending it, presumably being content with simply possessing it. When Manfred was younger, he always feared that immigrant families could take even more resources away from him and his family through their claims on social welfare. Later on, he also voiced concerns about refugees, who did not work and received social welfare money as well. Mrs. Oblinger was, on the one hand, very engaged in helping othersalthough she had to cease her voluntary activities at a local food bank and as a paramedic due to her own health issues - and felt sorry for asylum seekers who had lost everything. On the other hand, she had always voiced some concerns and shown traces of hostility towards foreigners. 
It was only during the last waves of data collection that she seemed to have changed her views slightly, as she talked a lot about close friends, who were immigrants from Eastern Europe and who had become very important to both Mrs. Oblinger and Manfred.

When Manfred started elementary school, a test showed that he was highly talented and intellectually highly gifted. This resulted in him being bored in school and becoming an outsider because of his intellectual abilities and his personal interests - in contrast to his peers, he was interested in politics and other serious topics. Due to the weak infrastructure where the Oblingers lived, a lack of resources on the side of the family, and a lack of adequate support programmes in the region, Manfred's cognitive abilities were hardly stimulated. Manfred was, therefore, not able to develop competencies for actions commensurate with his intellect.

It became clear throughout all waves of data collection that Manfred's parents were overchallenged with raising their kids generally, and especially with their media education (the parents showed laissez-faire practices or sometimes even unmethodical restriction, see Chapter 7). At the same time, Manfred and his siblings had access to plenty of media to compensate for other shortcomings. This soon led to excessive media use, especially with Manfred, who developed a special liking for violent video games. These games challenged him intellectually and cognitively, and he was soon able to master difficult levels, thus boosting his self-esteem. His mother provided these games because she felt sorry for her son, who was an outsider with hardly any social contacts, as she would not let him play with children with migrant backgrounds in their neighbourhood. This led Manfred to start playing shooter games at the early age of six. Right up to the end of the study, Manfred remained very much into video games and found it easier to make friends online through various games than through any social contacts in his immediate surroundings. At the same time, he developed remarkable skills in programming and in using various tools to advance his game playing.

Manfred managed to find a place for training as an industrial management assistant-despite his intellectual abilities, he did not want to continue going to school or to pursue studies at a university, he wanted much rather to earn his own money as soon as possible-but he gave it up after only two months. After this, he became fully absorbed in his world of online game playing, until he managed to find a new training position in his desired profession of IT technician. When we last called 
Manfred, he seemed very enthusiastic about this position and it looked very promising. His self-taught abilities in using computer technology had finally transformed into a job opportunity. This job training now offered him a way to support his parents financially, to have money of his own and to realise his outlines for actions, while at the same time trying to better the situation of his family.

\subsubsection{The Fein Family}

At the end of the study, the Fein family consisted of Ms. Fein, her daughter Olivia, the younger son and the youngest daughter. The family was initially living in an apartment on the outskirts of their local town, an area with many immigrants and people with migrant background. Between our second and fourth data collection waves, Ms. Fein had a new partner with his own business. She also moved to another county, and both factors led to an overall improvement of her socio-economic situation although Ms. Fein herself had been unemployed throughout the whole study. After separating from her partner, who was also the father of the youngest daughter, she experienced a severe worsening of her situation. She was diagnosed with epilepsy and depression, was granted an early pension at age 33 and remained in treatment for her psychological problems. By the end of the study, she had a new, considerably older partner, with whom she had a less formal relationship.

During our second wave, Olivia, the oldest daughter, had troubles adjusting to her new surroundings. At one point, she threatened to commit suicide and was committed to a supervised living facility after her grandmother intervened. This seemed to have a positive effect in the beginning, but Olivia continued to display behavioural problems, such as masturbating in front of others (by that time she was ten years old). Olivia had always been affected by the problems and strains in her family, because the family climate was always problematic, even during periods of relative financial stability.

At the beginning of the study, Ms. Fein practised unmethodical mediation, but later she displayed total lassez-faire, was seemingly resigned to her fate and unable to take on any responsibilities. As a consequence, she was rather distanced from her children, had little interest in them and remained preoccupied with her own problems. Olivia characterised her mother as "cold-hearted" in one of our last waves and was longing 
for a trustworthy confidant. The relationship between Ms. Fein and her daughter Olivia was obviously damaged by the time that Olivia had spent in the supervised living facility. Both expressed feelings of estrangement after Olivia was allowed to return home. The relationship deteriorated further after a supposed incident between Olivia and her mother's ex-partner-in the last interview Ms. Fein indicated that her ex-partner was not allowed to see their daughter, Olivia's youngest half-sister, after a court-mandated visiting ban. The exact reason remains unclear, although the case had overtones of sexual abuse.

Olivia had reacted to the strained climate in her family and the alienation from her mother by displaying an overwhelming wish for attention. Her media usage indicates how her psychological insecurity made her seek images of an idyllic world. For a long time, she admired Hannah Montana, the star of the TV series with the same name. Subsequently, she became very interested in gossip about stars, and especially royal families, which served her as fantasies of consumption and wealth. Her desires were reflected in her outlines for actions, like, for example, marrying early and having a family, an expression of her longing for safety and comfort and a way for her to realise competences for actions. Social media served as a way for her to channel her feelings and to present herself as a sexually attractive young woman; she tried to attract attention via various social media channels, like Instagram and Facebook.

Ms. Fein seemed overchallenged by her socio-economic situation, and, above all, by her socio-emotional state, throughout the study. She had always been trying to find personal happiness with new partners as outlets for her sexuality-something that Olivia always noticed and was bothered by-as well as the prospect of more financial stability. However, all attempts failed. Sexuality and the longing for financial stability became the dominant themes in the family.

\subsubsection{The Öllinger Family}

The Öllinger family consisted of Ms. Öllinger, a single mother, and her only child, Viktoria. Ms. Öllinger was in poor health during most of the study, meaning she was unable to work. She experienced a number of misfortunes, ranging from three miscarriages, to complications after an operation, resulting in a coma and almost in death, to back problems, epilepsy and depression. By the end of the study, Ms. Öllinger had to spend most of her days at home, often in bed and unable to participate in social activities. 
The situation of mother and daughter became worse over the years, with the socio-economic situation collapsing after Ms. Öllinger found out that her ex-partner had used her name to amass debts online without her knowledge. Being unable to pay the debts off, Ms. Öllinger had to file for personal bankruptcy. By our last wave, she had finally been granted a disability pension, which enabled her to "get by". Divorced twice, Ms. Öllinger was living alone with her daughter for the last years of the study. As she grew up with foster parents, she did not have a strong and reliable support network. This family's options, outlines and competences for actions had become extremely limited by the complex dynamic that had evolved over the years.

Despite the generally strained situation, mother and daughter were very happy with their apartment, a fairly new one on the outskirts of a bigger town, which they were able to finance with the help of housing benefits. Apart from the good housing situation, the family struggled with their financial problems and the resulting social exclusion. Due to her mother's illnesses, Viktoria was forced to take on a lot of responsibilities at an early age, a burden which left its marks on the young woman. She demanded a lot of herself, while her mother suffered from fear of loss and consequently clung to her daughter. This dynamic led to a form of reversed roles in the fifth and sixth waves of data collection. The fear of loss became a dominant theme in the family: Ms. Öllinger was afraid of letting her daughter grow up and become independent, as she might leave her on her own. Viktoria was afraid that her mother could die, that she might not be strong enough to support her and she did not want to leave and disappoint her, while at the same time dreaming of going abroad and having new experiences. The pressure and the burden may well have caused the stomach aches Viktoria developed and her early signs of anorexia. Viktoria had been adjusting her options for actions to accommodate her mother, not just as far as her behaviour and duties were concerned, but also regarding her media use. She shared her Facebook account with her mother, watched the TV shows the latter liked, while Ms. Öllinger herself kept in touch with Viktoria through WhatsApp as soon as Viktoria left the apartment to go to school. Ms. Öllinger's mediation practices were dominated by amicability (see Chapter 7). At the same time, the social media helped Viktoria to engage in friendships. She communicated with her best friend through WhatsApp, where they sent each other pictures of their outfits, thus giving her the chance to be a "normal" teenager. This form of media 
usage provided a form of independence for Viktoria, which she was otherwise unable to obtain. Viktoria remained torn right up to the end of the study, as she tried to show her mother that she had not grown up yet (by, e.g., running around naked and showing her still girlish body or cuddling with her mother) but she longed for a life of her own, without the limitations she had been experiencing over the years.

\subsection{The Families of Type 2}

Families No Longer, or to a Lesser Degree, Strained Socio-Economically but still with Problematic Socio-Emotional Relationship Structures. (Holzner, Weiss, Rohringer, Hirtner)

The families of Type 2 were characterised by new family constellations and new experiences of separation. As a result, the climate in these families was very strained, and their doing family affected.

In contrast to the families of Type 1 above, these families had seen an improvement in their socio-economic situation towards the end of the study (waves five and six), but the relationships among the family members had largely remained problematic or worsened. The family members were, by and large, overwhelmed by this situation. Mrs. Holzner, for example, had married a new husband, and this led to an improvement of her financial situation due to his stable and fairly well-paid job. She even started a new family, with two more sons, but the relationship to her "old" nuclear family, especially to her son, Benedikt, remained strained. Ms. Weiss, on the other hand, inherited real estate and managed to improve her financial situation through renting it out, but her relationship to son, Alfons, remained unchanged. Neither the newly married Mrs. Holzner nor Ms. Weiss, who had been separated from Alfons' father for all of the study, seemed interested in their sons and in maintaining a relationship with them, so that relations were inevitably strained. The Rohringer family and the Hirtner family also improved their socio-economic situations, although not to the extent of the Weiss and Holzner families. However, climate within their family was similarly strained. Relations among the Hirtners, their doing family, was considerably affected by Ms. Hirtner's separating from her partner, thus destabilising the network within the family.

All four families of this type showed signs of overextension in their coping strategies, as their everyday lives as nuclear families mirrored their 
strained socio-emotional circumstances. This overextension was also visible in the parenting and in the parents' approaches to regulating media use and educating their children about it, both functions characterised by a lack of interest.

It is noteworthy that three of the four families of this type consisted of single mothers with their children (Weiss, Hirtner, Rohringer). Before she remarried and had two more children with her new husband, Mrs. Holzner had also long been a single mother; her son, Benedikt, and his siblings had lived in supervised living facilities since wave three.

\subsubsection{The Case of Benedikt Holzner and His Family}

\subsubsection{Situation and Climate of Relationships Within the Family}

The life of Benedikt (16 years old in 2016) and his family had been marked by considerable turbulence over the years. It was particularly affected by a court-mandated removal of the children into supervised living facilities between waves two and three.

When the study began, Mrs. Holzner and her three children, Benedikt being the youngest, were living as lodgers in a terraced house in a rundown neighbourhood. The family disliked the neighbours, and especially the prevalence of immigrants and people with migration backgrounds, but they were, nonetheless, content with the location and the opportunities available for the children.

The whole family suffered from the violence of Mrs. Holzner's ex-partner, and she was struggling to get by with the social welfare money she received as a single mother. Benedikt was particularly traumatised by previous physical abuse, had trouble concentrating on anything, was diagnosed with ADHD and suffered from uncontrollable fits of rage. When he was in treatment as a five-year-old, his therapist certified that Benedikt had the developmental level of a three-year-old. This deficit became also clear to us in our first interview with the young boy. His family was not able to provide the help or stability necessary for him to cope with his traumatisation. During this time, Mrs. Holzner had very few options for actions and consequently hardly any outlines for actions.

Shortly after our second interview in 2007, Benedikt and his siblings were placed in special supervised living facilities after the child protection services intervened. Accordingly, our next interview only involved Mrs. Holzner, since Benedikt could not be reached in the facility. 
In 2012, we could not interview them at all, because Mrs. Holzner had remarried and changed her name, which made it hard to contact her. Subsequently, she did not want to participate due to an ongoing court case affecting her and her children, refusing any explanation. Our next interview then took place in 2014. In the meantime, her older children continued living apart from her in various facilities, and Mrs. Holzner started a new family with her husband. She was living together with him and their son in the apartment that her husband had previously bought together with his ex-partner. Between the last two waves of data collection, they had another son together.

By that time, Benedikt's older brother and older sister had moved back to the city to pursue job training, but they were still living in supervised living communities for adolescents. Benedikt's school and living situation remained somewhat unclear, as his mother was always referring to a supervised living facility, while the boy himself talked about a boarding school that he was attending-which was actually the case. Mrs. Holzner had never visited her son at the facility or seen his school (she was not even sure about the exact location). She hardly showed any interest in any aspect of his life, even going so far as to disparage and mock him. While she always used to describe him as lazy, unmotivated, unkempt and so on, our interviews with the boy himself, showed him to be, on the contrary, very resourceful and proactive in his education and later search for job training. At the same time, his mother never bothered to get in touch with the school or the carers in the living facility, presumably thinking that everything was in order as long as no one called her. She also stated that she did not think very highly of the carers and made especially derogatory remarks about the female carers.

It became very clear during our last interviews that Mrs. Holzner was not interested in Benedikt and his life-disinterest can be seen as the main characteristic and attitude in the family. She was consequently hardly able to provide any information about him, his interests, his media use, his future plans or even his relationship to his biological father, her ex-partner. Mrs. Holzner seemed solely focused on her new family, putting all her energy into it, whereas Bendedikt was seen rather more as a visitor, looking in on his half-siblings at weekends now and then.

While the relationship between Benedikt and his mother was troubled, he always maintained a close relationship with his older siblings, as well as later with the younger ones too. His older siblings are his central reference persons, and he called them his family, assigning a place close 
to him in his network map (Fig. 8.4). At the end of the study, Benedikt also talked about his girlfriend, who was living nearby and whose family had shown kindness in accepting him.

Benedikt's plan was to finish compulsory education-he had to repeat a school year after changing from an academic secondary school to one with a focus on information technologies - and to start job training as soon as possible in order to become independent and to earn his own money. He succeeded in securing the desired job training and organised everything by himself. His outlines for actions were very clear and straightforward in this regard, and he appeared very grown-up and focused during the last interview. With Benedikt, it seemed that the treatment and therapy he received over the years, combined with a positive learning environment in his living facility, led to a general improvement of his development, there being no trace of his former developmental deficits by the end of the study.

It was always clear that Benedikt felt comfortable in his new living situation and that he profited immensely from the intervention in his previously troubled circumstances. The facility provided him with the stability and the available reference persons he was lacking at home, and he seems to have built his whole life around this facility and the school,

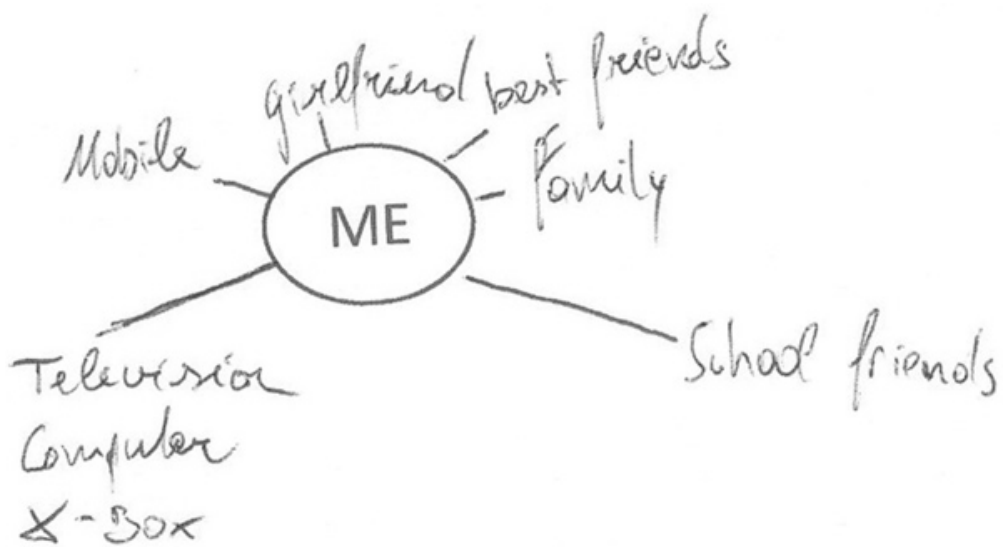

Fig. 8.4 Network map by Benedikt Holzner in 2016 (Tracing based on the original, translated and anonymised by the authors) 
indeed considering it his "home". Our impression was confirmed by Mrs. Holzner's phone call at the end of 2016, explaining that she had basically lost contact with her son after the last interview. Benedikt himself could not be reached for a last short interview. While we cannot posit a causal link between his development and the intervention in his family, Benedikt was, in fact, the only child from one of the very strained families in the panel, who appeared notably confident, balanced and selfpossessed by the end of the study. Given that he was one of the most serious cases when the study began, his development can be seen as the exception among our subjects.

\subsubsection{Media}

Benedikt used the media intensively as a child. They were his main source of information, his companions and often his only leisure time activity. When the study began, Benedikt spent most of the day in kindergarten, but he and his siblings were watching TV before they left and re-commenced this activity as soon as they returned home in the afternoon. They often watched until 9 p.m., even longer on weekends. Benedikt himself claimed in 2007 that he was "always" watching TV. He owned a broad range of merchandise articles and referred to his DVDs, CDs, the TV and video games as his "favourite things in life". His mother showed laissez-faire practices because of the everyday demands on her; she accordingly expected that kindergarten and school or media would teach mediation practices (see Chapter 7).

All this changed drastically when Benedikt moved to the supervised living facility. Due to the missing information from 2010 and 2012, and because Mrs. Holzner was, for the most part, unable to provide any information about her son's media use, apart from the fact that she thought he was "addicted to media" (2012), his actual use could only be reconstructed through later interviews, but it became clear that it was meticulously controlled and regulated in the facility. At the same time, it provided a lot of mediation, which found expression in Benedikt's very reflected and critical media use by the end of the study. It was true that the media still played an important role in his life, but in a very different way and on a different level from when the study began.

Like most teenagers in the panel, Benedikt became very interested in various social media services, like YouTube, WhatsApp, Instagram and 
Snapchat-but he did not use Facebook. He also used online and computer games, like Age of War and GTA, and favoured television shows on commercial channels, but he was also very much into sports broadcasts and documentaries. His access to game playing consoles was still restricted by the rules of the living facility, and there were limits on internet access. In our last interview, Benedikt claimed that his smartphone was his most important media device, because it enabled him to contact his friends; the aspect of communication was very important to him. In 2016, when asked to take a picture of his favourite "media place", he took one of his smartphone. As he spent only very limited time at his mother's place, the smartphone was his most valuable media device, enabling him to use his favourite services and content wherever he went.

At the same time, he often handed his phone over to the caretakers when he wanted to concentrate on his homework. He liked to upload "selfies" on apps like Snapchat but appeared to consider carefully what he exactly wanted to post, and what not, and between the last two interviews he had deleted his Instagram account. In addition, Benedikt was interested in the news and used push-services on his smartphone to receive updates.

Mrs. Holzner's media use was mostly dominated by the radio and her smartphone. She usually watched television together with her husband. She claimed not to read anything, because reading affected her like a sleeping pill. Although the media have always played a central role in Mrs. Holzner's everyday life, her opinion about their actual relevance varied from wave to wave. In the beginning, she thought that the media were very relevant, but next time she denied them any relevance, only to change her opinion again at the end of the study.

\subsubsection{Parenting and Role of Socialisation Contexts}

The deprivation that Mrs. Holzner experienced at the beginning of the study translated directly into her options and outlines for actions, something particularly apparent in her parenting strategies. Being overwhelmed by the challenges she had to face as a single mother living on social welfare money, Mrs. Holzner delegated child-rearing and parenting to others, like the kindergarten, later the school, but also to the media. At the beginning of the study, Mrs. Holzner specially tried to mask her disinterest in parenting and in her children, as well as her inability to meet her own parenting goals, by presenting that as a deliberately chosen parenting style — she was always keen to display a supposedly 
laid back and open approach to parenting and child-raising, when she was in reality overwhelmed by the demands of raising three children on her own, while at the same time coping with other everyday challenges. Her situation often led to aggression towards the children, a lack of self-control and a neglect of the children for days. In our interviews, she declared that she left the children to fend for themselves so that they would become autonomous and self-reliable. She was never a fan of clear rules and claimed that anything forbidden was even more appealing for children, so she did not bother to set any rules or restrictions, for example, regarding the duration of television use. It seemed that Mrs. Holzner was glad that her children were occupied with the media, so that she did not have to put too much energy into entertaining them herself, as evidenced by their television watching. The issue of parenting and media education was later taken off her hands entirely when her children were removed by the child protection services.

Only after he moved to the supervised living facility, was Benedikt's media use monitored and regulated-not just in terms of duration, but also in terms of content. Benedikt reported that he enjoyed the clear rules and the fact that there was always someone available to answer his questions over media use or media content. Mrs. Holzner was, in fact, never available for discussions about media-related questions, even when Benedikt directly asked, and her new husband counted as an expert only on the technical aspects of media use. In our last interview, Mrs. Holzner said that she would not discuss media-related questions, because, in her opinion, Benedikt ought to gather his own experiences, and it was not her business to run after him. To her mind, this was an important part of letting go and of letting children grow up.

Discussions on media-related topics, but also on politics, only happened in the living facility. Benedikt enjoyed them, and it became clear in our interviews that he tended to reflect critically on the media and news coverage about, for example, refugees, where he distinguished perceptively between more and less reliable sources.

With Benedikt, it was clear that other socialisation contexts played much more crucial roles in his development than did his family after he was taken away from home. While the media were a central influence in the boy's socialisation during the first years of the study, they were later replaced by the carers and also the teachers in school as primary agents of socialisation. They had been very positively influential in Benedikt's development. There was a brief phase between our last interviews where 
Benedikt felt too much pressure in his school, so he decided to switch to another, a move which helped him to become more relaxed and motivated again.

Benedikt's siblings, and especially his friends, are also very important to him and act as other relevant contexts of socialisation. For example, his idea of applying for job training as a cable-car engineer was inspired by one of his friends.

Overall, it can be said that Benedikt was able to acquire resilience and that his options for actions, but especially his outlines for actions and the competences to put them into practice changed considerably under the influence of different surroundings and contexts of socialisation over the years.

\subsubsection{Other Families of Type 2}

\subsubsection{The Weiss Family}

The family consisted of Ms. Weiss, a single mother, her son, Alfons, and his younger half-brother. Ms. Weiss had a relationship with a new partner during the second half of the study, but it remained unclear how serious the relationship ultimately was. Alfons had been living separated from his biological father since before the study began, a situation that he was constantly struggling with.

Between the fourth and the fifth waves, Ms. Weiss inherited real estate from her father and was thus able to improve her financial situation. At the end of the study, she claimed that she did not have to work anymore, since she was able to live from the money she received from renting apartments out. Ms. Weiss had always been a very economical person. When she was about 20 years old she took out a loan to buy the family's apartment, where they lived during the first five waves. This apartment had increased in value over almost 20 years and was sold in order to acquire a nearby semi-detached house. Throughout the study, Ms. Weiss was preoccupied with money. She always worried about not having enough and tried to downplay her financial situation. In this context, she never seemed to carry out her outlines for actions to her full satisfaction. It appeared that she was constantly thinking of new ways of getting additional money, for example, taking in a foster child, with the additional welfare payments that brought. It was also possible that her decision not to let Alfons live with his father, a wish he openly expressed 
over and over again, might also have had something to do with alimony and child support payments. She was, for example, afraid what the refugee crisis and the asylum seekers might cost her as a tax-payer and worried that the welfare system - that she made use of herself between the last waves-might suffer.

Throughout the years, Alfons made no secret of the fact that he would rather have lived with his biological father, who lived in a mountain region and had a farm. He visited his father on some weekends and during parts of the summer holidays, but constantly suffered from their separation, so that it seemed his mother was trying to get back at her ex-partner through their son. We often had the impression that Ms. Weiss was venting her anger at her ex-partner on Alfons as well. It was clear that she favoured her younger son, of whom she always spoke in a very positive way. In fact, it sometimes seemed that she was trying to steer the interviews away from Alfons towards her younger son, about whom she liked talking. Alfons did not really lack anything, as his mother made sure that he was well dressed, had everything he needed and helped him to participate in leisure time activities and selected clubs, but her interest did not seem to run much deeper than catering to basic needs. The relationship between Alfons and his mother and between Alfons and his half-brother thus remained problematic throughout the study. In this context, the media played an important role for Alfons at an early age. He found orientation and diversion in them, while, at the same time, Ms. Weiss openly stated that she was not really interested in her son's media use and showed laissez-fair practices in monitoring it (see Chapter 7). Thus, she did not make any attempts at guiding his media use or inculcating any media literacy. In her opinion, schools were responsible for teaching these skills. When she used media together with her children, Alfons was often excluded, whereas his younger brother was always there.

All in all, Alfons' wishes and feelings were of no great interest to his mother, at least not if he did not do everything the way she wanted him to. Alfons' outlines for actions and competences for actions had been hindered through the bad climate in the family. By way of coping, he started to withdraw himself from it and, for example, concealed any money he got from his father, or did not mention the new smartphone that his uncle gave him.

By the end of the study, Alfons had started job training in the nearby city, where he lived in a boarding school. With this step away from his 
home, Alfons had access to new and self-determined outlines for actions and was able to develop competences for actions, but he, all the same, seemed to be uncomfortable with his situation.

\subsubsection{The Rohringer Family}

The Rohringer family consists of Mrs. Rohringer, her oldest son from her first marriage (who had already moved out), her daughter, Isabelle, and the youngest son. The family lived in the same apartment in the countryside throughout the study. Mrs. Rohringer separated from her partner, the father of Isabelle and her younger brother, between our first and second interviews. He was an alcoholic, a problem which burdened Isabelle particularly.

By the third wave, Mrs. Rohringer had a new partner, a business owner who employed her in his transportation business, leading to an improvement in the family's socio-economic situation. Although the new partner was also able to bring more stability to the family, the socio-emotional situation remained strained, especially with regard to Isabelle, who suffered under her father's drunken phone calls or his cancelling of meetings. Isabelle appeared traumatised by her parents' separation and had to undergo therapy to cope with her problems In addition, Isabelle was struggling in school because of her dyslexia, which remained a problem right up to the end of the study. The problems of her children (be it Isabelle's dyslexia, or other issues in school), in combination with the separation, seemed to overwhelm Mrs. Rohringer, and she tried to maintain control over the situation by seeking to exert control over her children, yet she never communicated clear rules but set them randomly as she saw fit.

According to Mrs. Rohringer, the media had no major significance for Isabelle in the first three waves, especially since the latter had problems concentrating on anything for any length of time. From what Isabelle said herself, it seemed that she was a rather frequent media user, after all, and also possessed a broad range of merchandise products that were very important to her. As she grew older, German reality shows became her favoured television content. These were referred to as "trash TV" in the sixth wave by both mother and daughter, but nevertheless they were very important to the girl. Indisputably number one media device for Isabelle in the sixth wave was her smartphone for communicating with friends or for social media, like Facebook and Snapchat.

Although the relationship between Isabelle and her mother was initially good, and Mrs. Rohringer acted as an important pillar for Isabelle, 
they started to argue more often towards the end of the study, especially because Mrs. Rohringer's urge to control her daughter meant she disregarded her private sphere, displaying arbitrary control more than ever and exploiting her dominance (see Chapter 7). A particular dispute centred on the mother's apparently random, but actually comprehensive, monitoring of Isabelle's short text messages and WhatsApp-messages. The girl began to suffer under her mother's dominance, while she herself often seemed to lack drive and motivation, as well as any clear idea of her future. By the end of the study, Isabelle was wanting to move out, yet she herself did not seem able to develop any outlines for actions she could actually implement. For Isabelle, the media became important tools for keeping in touch with friends and for entertainment purposes. She enjoyed various fictional television series as well as "reality" shows, something her mother approved of, regarding them as valuable lessons about life.

\subsubsection{The Hirtner Family}

The financial situation of the Hirtner family was very precarious at the beginning of the study, as Mrs. Hirtner and her then partner were both unemployed. Mrs. Hirtner's son, Mario, regarded her partner as his father, although they were not biologically related. However, that was something he only learnt when the partner and his mother broke up after the fifth wave. Mrs. Hirtner found a new partner between the fifth and sixth waves. The financial situation of this newly-formed family improved during the study, especially since Mrs. Hirtner was working full-time at its end. The Hirtners lived in the same apartment throughout and were mostly content with the housing situation and the neighbourhood. It was only in the sixth wave that Mrs. Hirtner complained about refugees being housed near the apartment. In fact, she had been robbed right in front of the entrance to their block and afterwards did not feel safe anymore.

Mrs. Hirtner and Mario's biological father had been separated for a long time when the study began, and there was no contact between Mario and his father, since he did not even know that he existed. The only father Mario knew as a child, his mother's then partner, did not keep in touch with Mario after he left, but Mario did quickly accept his mother's new partner as a close person of reference.

Mario always had a very close relationship with his mother and could also do what he wanted when using the media. His mother was not 
interested in this activity at all and displayed a laissez-faire approach to it (see Chapter 7). But the relationship became more and more distanced after our fifth interview. Mrs. Hirtner felt unable to cope with her son's need for closeness. Especially during the last interview, it became obvious that Mrs. Hirtner had an alcohol problem. She seemed to be drinking quite frequently, neglecting her son and even becoming aggressive towards him. This led to Mario withdrawing from his family and focusing on video games. His mother was not able to help and comfort him when Mario had to quit his job training because of his fear of heights, she even began to put pressure on him and make fun of him, which led to his further withdrawal. In response, Mario redirected his outlines for actions and tried to "function" the way his mother wanted him to. This socio-emotional burden had an effect both on the climate within the family and on Mario's everyday life. He even withdrew from his friends and dived into his world of video games, where the social contacts he made replaced his previous relationships. At the same time, he was able to acquire many technical competencies through his interest in game playing and was in the end able to secure some new job training in the IT sector. This meant a chance for him to become more independent, but it was still obvious that the strained situation at home continued to trouble him.

Mrs. Hirtner was meanwhile suffering under the feeling that she had failed in realising her personal outlines for actions. In the light of these circumstances, doing family among the Hirtners was marked by an overall inability to cope with relationships and challenges.

\subsection{The Families of Type 3}

The Families Strained Socio-Economically, but Stable Socio-Emotionally and Relatively Competent. (Stab, Aufbauer, Boll, Ebner, Kaiser)

The strained socio-economic status of these nuclear families did not change, but they were able to improve their socio-emotional situation over the years. Although they experienced socio-economic restrictions, they appeared to be much less strained in coping with everyday life and doing family when compared to the families of Type 1 and Type 2. They became more and more successful in handling life under their existing conditions, and, although their options for actions were experienced as 
limited, they managed to compensate for the strains imposed through stable and strong relationships.

These families were mostly satisfied with their situation in life: a clear distinction from the Type 1 and Type 2 families. The Stab, Kaiser and Ebner families from Type 3 had managed to cope with their aggravated conditions very well from the beginning of the study onwards. The Boll and Aufbauer families, on the other hand, were able to stabilise their socio-emotional structures over the last two waves and subsequently managed to cope with their everyday lives fairly competently. The families of Type 3, and especially the mothers, were striving for harmony and an open approach to parenting that is focused on a lot of mediation. By the end of the study, the children who were our subjects, Amelie Aufbauer, Gregor Boll, Elisabeth Ebner, Torsten Kaiser and Simone Stab, felt very comfortable and secure in their families. Some of the siblings in some families did experience troubles at different times, but, all in all, the families, as such, were able to manage these situations and to find solutions together.

\subsubsection{The Case of Simone Stab and Her Family}

\subsubsection{The Situation and Climate Within the Family}

Ms. Stab was an immigrant from Eastern Europe, who had been living in Austria for about 20 years when the study began. Simone (15 years, 2016) was her oldest daughter and there was a younger son, Simone's half-brother. The family lived in the countryside throughout the study, but they moved twice on financial grounds. The family was mostly very satisfied with their housing, although, in the last interview Ms. Stab did state that she was somewhat dissatisfied with their apartment, because it had become both too expensive and too small for the family. There were also conflicts with the block's janitor, who made a lot of noise when working around the house. At the end of the study, Simone declared herself very satisfied with the apartment and with her own room, especially because of the "Indian, Buddhist and Native American flair" they had created, and which Simone's room also featured (including peacock feathers and a Buddha tapestry on the wall and a three-part dreamcatcher hanging from the ceiling). 
Simone's younger half-brother was not living with the family during the week anymore after moving into a supervised living facility following conflicts in the family.

The financial situation of Ms. Stab and her family was rather strained throughout the study. Her university entrance qualifications from her country of origin were not officially accepted in Austria, and, as an immigrant from Eastern Europe with imperfect German, she faced difficulties on the job market, forcing her to work part-time as unskilled labour and sometimes be unemployed between jobs. An attempt to set up her own business following training as a masseuse had not been successfully realised by the time the study ended. Her part-time employment as a waitress and masseuse did not alleviate the financial situation of the family much. What was clear throughout the study was her unceasing will to provide for her children and to make a good life within her limited possibilities. The children never lacked the basics, but extraordinary costs, like car repairs, particularly challenged the family. Through all these challenges, Ms. Stab always kept a positive outlook on life, tried to appreciate what she had in life and to make the best of every situation without complaining or blaming others. The only thing she kept hoping for was a steady partner and step-father for her children. Unfortunately, she did not appear to meet any suitable candidates, so that her relationships were never successful.

As a single mother-Simone's father had left her when the girl was two years old-Ms. Stab was always struggling to make a living, which meant that she often had to leave her children with others, or in daycare, a fact that she declared she deeply regretted, because she regarded them as her absolute priority and felt she had not supported them sufficiently. However, Simone declared in her interviews that her mother had indeed tried to support them in many other ways. Her relationship with her was clearly very close and built on trust, with Simone saying explicitly that she had "the best mother".

The contact with Simone's father had continued to varying degrees. Only after her father remarried did she experience some problems maintaining the contact, since her father's new wife seemed to be jealous and was trying to undermine his involvement with Simone. In the last phone interview, Simone said that the contact between them has improved again after her father divorced his wife.

Simone's everyday life was rather busy. She had many hobbies and also took part in club activities, especially around the fifth wave, like soccer, 
karate and volleyball, and she was learning to play the guitar. After changing schools between the fifth and sixth interviews, there was not much time left to pursue those hobbies or to meet with friends. During the sixth wave, she was attending a polytechnic secondary school, allowing her to focus on sculpting, which she enjoyed. She was set on finishing school at university entrance level and going to college afterwards. But before starting college she was planning on travelling, maybe as part of a work-and-travel programme. It was obvious that Simone wanted to do whatever she could to escape the restrictions of social disadvantage in her own life. Her outlines for actions and her attempts to acquire the necessary competences were firmly directed towards this goal. She did not want to get diverted, not even by friends or a boyfriend, despite the fact that friendships were in general very important to her.

The family situation was overshadowed by problems with Ms. Stab's son during the last two waves. His computer game usage had escalated, and Ms. Stab felt that her son was lacking a father figure. On her own, she was not able to help him get out of this situation, although she tried hard to. There were also many disputes between Simone and her brother, and in the end Ms. Stab decided to get help from outside. Her son moved to a socio-educational living facility, where he was living during the week and in which he received counselling. The situation improved and the relationships between both mother and son and brother and sister seemed to have recovered.

\subsubsection{Media}

Simone's media equipment can be best described as modest and functional. She had always had access to basic devices, like a laptop or a phone, but usually they were not the most modern or most expensive ones. For example, her father bought her laptop during the fourth wave because she needed it for school. She was still using it up to the end of the study, when it was supposedly not suitable for her computer-aided classes, as it was already outdated. When the study began, Simone favoured the television and related to characters like Mowgli from the Jungle Book or Peter Parker from Spiderman, which mirrored her experiences of loss and loneliness, with her father being absent and her mother having to work. Money and upward social mobility were topics that interested her and influenced her choice of media content, so that she favoured Hannah Montana or various casting shows. Later, she developed more interest in sitcoms or crime series, while still liking casting shows. 
Simone had never been much of a reader, unlike her mother, who often talked about books on topics such as psychology, philosophy and religion. Sometimes, Simone would look into magazines for teenagers, but apart from that, reading was not important to her. In our sixth interview, she mentioned a book about the Dalai Lama; this apparently was the first book to interest her.

From the fourth wave onwards, Simone's most important media device was the smartphone. Towards the end of the study, it became even more important, as it helped her to stay in touch with her friends, even though she did not have much time to meet them because of her workload in the new school. It was also important for her as a way to listen to music (from the time she gets up until she goes to bed, so she said) and to take pictures. Photography is one of her hobbies, and the phone helps her to share the pictures she takes on social media. The smartphone became her constant companion.

She had been using social media intensively since 2014, especially Facebook, Instagram and Snapchat. Her list of some 2000 friends on Facebook was quite big at that time, and even after a "clearing out", there were still 1600 left by the end of the study. But she did not share pictures on Facebook, only on Instagram, where she had stricter privacy settings.

YouTube also became more relevant to her towards the end of the study and supplanted other social media platforms. She listened to music on the platform but also followed news and items from YouTubers.

Ms. Stab's media use is, in fact, quite easy to assess. She used the internet to manage her bank account and to upload documents-for example, from the state employment agency-and she sometimes used YouTube. Earlier in the study, she used online dating platforms for a while, in the hope of finding a new partner, but ceased these activities after a couple of unsatisfactory dating experiences (one of the respondents was, e.g., an alcoholic). However, it does seem that, apart from books and the phone, the media have always played more of a subordinate role in her life. Growing up in Eastern Europe without electricity and, hence, without the media probably meant she could more easily function without the latter. She was very critical towards the media, although she is also aware of their services and did acknowledge making use of them herself. In the early years of the study, Ms. Stab had felt the need to protect her children from the harsh reality shown on the news, but later she changed her opinion. She had no tolerance for 
pornographic and especially violent media content, and often argued with her son, who was obsessed with violent video games. Her critical opinion was reinforced by her son's situation towards the end of the study, although she also said that it was necessary to stay up to date with developments.

Although her children became more skilled with the use of media, as she said in our fifth interview, Ms. Stab always tried to teach them awareness of the inherent risks and dangers and tried to share her own experiences with them. Simone was also able to learn from mistakes, as with one particularly high phone bill. That problem was solved together with her mother, and Simone was from then on alert to such dangers. Whenever Ms. Stab encountered a topic or a situation that she felt not competent enough to solve, she got help from someone more knowledgeable. Her attempts to raise her children to be critical and to question things was mirrored in Simone's media use. She expressed her scepticism over online content clearly and did not believe everything she saw. She also knew how to get help with problems beyond her abilities.

\subsubsection{Parenting and Socialisation Contexts}

Ms. Stab had one clear goal in her parenting: she wanted to raise children with independent personalities capable of standing up for themselves. As far as Simone was concerned, Ms. Stab was satisfied with her development, although she admitted to mistakes. With her son, she felt less successful and attributed that, to some extent, to the detrimental lack of a father figure. Despite the problems with him, Ms. Stab never gave up on her son, and their relationship did seem to improve.

Simone mirrored the positive attitude of her mother and seemed very independent, grown-up and wise for her age, something her mother attributed to Simone having to take on responsibility for herself very early in life, while her mother was absent at work. Our impression at the end of the study indicated that Simone was well-equipped with the important abilities for managing her own life. Ms. Stab was always keen to teach her children her values, like honesty, solidarity, frugality and her beliefs in God and altruism. Simone reflected this attitude in one of our interviews, where she said that she did not have any particular wishes, but that she was hoping for a better and more peaceful world, in which it was possible "to pet lions" (2010). Ms. Stab's parenting style was marked by much mediation and attempts to teach her children necessary skills as best as she could. One example is the way she always included 
Simone when she was dealing with online-banking, so that the girl could see and learn how this works. Here, Ms. Stab combined amicability and child-centred mediation practices (see Chapter 7).

Ms. Stab was highly critical of herself and of her own actions. She was convinced that, like most parents, she also made mistakes while raising her children, but we were persuaded that she always tried to do her best and to do it in a loving way.

Our interviews with Simone and her mother were remarkable in the context of the panel. Hardly any other interviews with parents and children showed views corresponding as much as theirs did. Of course, Simone became more independent as she grew older and did not share everything with her mother anymore, but, all in all, it was always clear that her mother remained her closest reference person, on whom she knew she could always rely. Hence, she also drew her mother in close proximity to her in her network map (Fig. 8.5). In our last phone interview Simone said that she sees herself as "a solid and mature person".

Friends were always very important to Simone, and she had a group of close friends, with one best friend whom she had known for years, and she had a boyfriend for two years, However, contact with her friends dropped off after Simone changed to a new school, which took up a lot of her time and energy.

For Simone, her family was always the primary context of socialisation. Even with growing independence, and the growing importance of friends, her family was for her the safe haven to which she could return and on which she could rely.

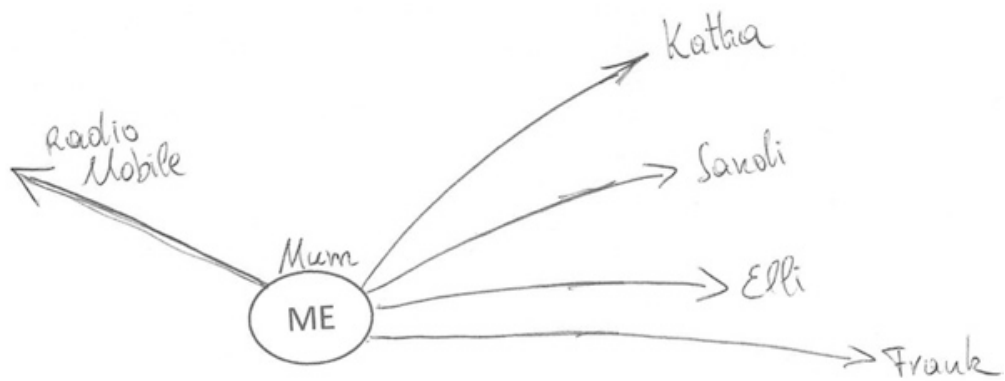

Fig. 8.5 Network map by Simone Stab in 2016 (Tracing based on the original, translated and anonymised by the authors) 


\subsubsection{The Other Families of Type 3}

\subsubsection{The Aufbauer Family}

This family was one of those severely challenged financially when the study began. By the end, the situation had improved somewhat, but Ms. Aufbauer, a very intelligent and seemingly well-read woman, had most of the time been supported by social welfare and the childcare allowance. She had four children, all from different fathers, and described herself as a single mother by choice, having no interest in any man in her life. The family situation could be described as turbulent, with a baby always needing care, so that the older children usually had to look after themselves.

In addition, the family displayed Ms. Aufbauer's permanent urge to change things. They moved a lot during the study, that itself being also a way of receiving new housing benefits, once the one for the old apartment had ended. Amelie, one of the daughters, even called herself a "moving expert", although the many school changes and the need to find new friends seemed to burden her. By the end of the study, Ms. Aufbauer appeared to have found some balance in her life, as the climate within the family was good, and previous conflicts between the siblings as between mother and children had mostly been resolved. This improvement was due in part to the oldest daughter moving out of the apartment, thus removing some of the tension, as the apartment had become too small for so many people. The constant proximity to each other had triggered conflicts between the grown-up, older daughter and the rest of the family. Only Amelie was, apparently, somewhat disappointed when her sister, her close friend and reference person, moved out and left her behind.

The relationship between Ms. Aufbauer and Amelie improved considerably after the mother supported her daughter during a difficult time following a problematic relationship and break-up. Amelie had a partner who tried to take possession of her and who wanted to control her. Her mother stood by her and finally helped her to break free. Amelie is a very pretty and very intelligent, confident young woman, but when it came to men and relationships, she seemed to lose her confidence and became insecure. She tried to master this problem through self-help books and was thus able to independently strengthen her competences for actions and set herself new outlines for actions.

The dire socio-economic situation of the family, and the limitations that Amelie experienced through it, left their marks. Amelie was dreaming of a better future with financial independence. Her media-use 
mirrored her fantasies of consumption and her desire to acquire luxury goods. Various German reality shows addressing these topics were among her particular favourites (e.g., a show called Shopping Queen, where women get a certain amount of money to spend on an outfit) and even served to develop fantasies about her own future: one example involved becoming a real estate agent. She also liked to pick content that dealt with finding one's own way and becoming famous. Together with her mother, she liked to watch the well-known series, Sex and the City, treating it as a mother-daughter viewing ritual. While this particular practice may be classified as amicability (see Chapter 7), Ms. Aufbauer's dominant media practice was characterised by laissez-faire (see Chapter 7). For Amelie, the media always represented a constant in her otherwise very unstable circumstances. Their importance for her over during the study could well be described as tremendous.

In order to earn a lot of money later on, she was looking for wellpaid business sectors. At one point, she was-inspired by her favourite television show-dreaming of becoming a real estate agent, especially for Russian clients. Later, she was planning to pursue a career in business administration or to study economics, and during our last phone interview, she was contemplating studying medicine. Their permanently straitened circumstances always marked the whole family's outlines for actions, but they stood out in Amelie's particular outlines for actions, with her striving for financial security, strength and resilience.

\subsubsection{The Boll Family}

The story of the Boll family was one marked by various misfortunes, from which the family was, however, always able to recover. When the study began, Mrs. Boll had a husband and a large family of nine children, a tenth child had already moved out. They were living on a farm and managed to get by on what the farm provided and through additional sources of income, like Mrs. Boll's dog breeding business. The farm was isolated in the countryside, meaning that Gregor and his siblings did not have many social contacts, and the media were often used to compensate, or to keep the children occupied. Despite this, the media did not, for a long time, play a big role in the life of Gregor and his siblings. Compared to other children in the sample, they spent a lot of time outside, playing on the farm and playing with each other. When they used television, the viewing was often actually initiated by the parents. 
Overall, the family situation was fine, and the family members seemed quite happy. Then Mrs. Boll was diagnosed with cancer, had to undergo treatment. While in chemotherapy, she found out that her husband had had an affair with the children's elementary school teacher. She filed for divorce, moved out of the house and later moved back to her old home in Northern Germany, taking the younger children with her. Contact between her and her ex-husband was basically non-existent by the end of the study, and it is clear that she was never able to forgive him for his behaviour, being deeply shocked by the events, as she believed they led a happy life together.

Mrs. Boll had to get by on few financial resources, since alimony payments were either infrequent or did not come at all. However, she did not want to sue her ex-husband and found other ways to manage everyday expenses. The region she had moved to was one with very low prices for houses, so she was able to buy a cheap, old house with the help of friends. After some time, she was also able to restart her dog breeding business, which provided an important source of income, so that, together with her invalid's pension and a pension from one of her previous employers, the situation was stable.

What remained of the large family bonded closely after the misfortunes, and it was clear throughout the last years of the study that Mrs. Boll had managed to slowly expand the limited options for actions for herself and her children, thus expanding their horizons. With the exception of Gregor's older sister, who displayed very problematic behaviour for some time after the move, all the children managed to become independent and to find work near their mother, whom they now in turn wanted to support. After a certain adjustment period, Gregor seemed to settle into his new surroundings and had hardly any contact with his father anymore. He took his mother's side and could not understand his father's actions. The relationship to his older siblings in Austria was very good, and they were very close and important persons of reference.

After he moved to Germany, the social media began to play an important role in Gregor's life, since they provided a way to stay in touch with friends and family from back home. Ever since the move, we could characterise Gregor's motives for media usage as communication and participation in group communication (including his family, his school friends and a group that always met in the local pub) (see Fig. 8.6). Finding information and entertainment were other motives as well. 


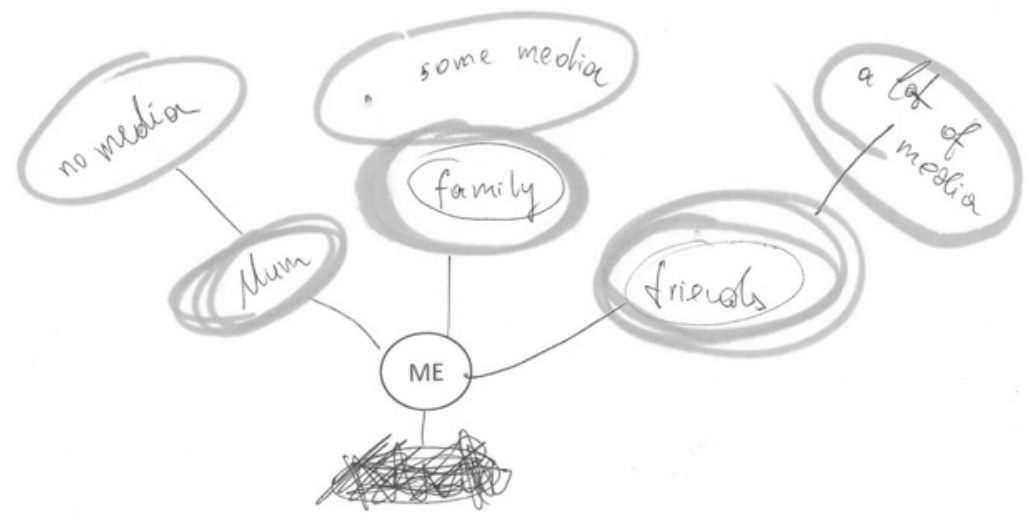

Fig. 8.6 Network map by Gregor Boll in 2016 (Tracing based on the original, translated and anonymised by the authors)

Gregor and his older twin brothers like using the media (e.g., computer games) together in the brothers' apartment. By the end of the study, it seemed that Gregor was using many more media devices and services than before moving to Germany. His parents had no time to monitor their children anyway, but evinced laissez-faire practices (see Chapter 7). However, it never appeared that Gregor was using the media entirely uncritically.

In this context, Gregor was able to develop his own perspectives and to acquire the necessary competences for action. His outlines for actions always included supporting his mother, something he did not see as clashing with his wish for independence.

\subsubsection{The Ebner Family}

The Ebner family, consisting of Mr. and Mrs. Ebner and their two children, suffered under limited socio-economic circumstances throughout our entire study. Mr. Ebner was working on the small farm where he and his family lived. At the beginning, the family was living in an old farm house without heating and suffering consequent problems with mould. They even led to the Ebner's son developing asthma. Later, they were able to move into a newer house next to the old one and viewed this change as a tremendous improvement of their situation. Although the location of the farm is somewhat remote, the family felt comfortable 
there. In contrast to the socio-economic, the socio-emotional situation of the family and the climate within the family were very good during the entire study. The parents' relationship worked well, and they got married after initially living together. The children had a good relationship with their parents especially in the case of Elisabeth, who was very close to her mother. She said that her mother was her most important person of reference and also her role model. Elisabeth and her brother had a very close relationship right through the study, obviously being extremely fond of each other and never really arguing about anything. Although the parents had to work hard to make a living, it was important to them to engage in many family activities and to spend as much time together as possible.

Compared to the other families when the study began, the Ebners possessed only a very limited range of media devices. They constantly acquired more and updated them as the study progressed, but they mostly used the media for practical reasons. They did not have very much importance for Elisabeth when she was younger, yet, from the fifth wave onwards, she did claim that she would be "screwed" without media, especially without her smartphone, which crucially served to stay in touch with friends and family, and to organise her everyday life. Until the fourth wave, Elisabeth was not very tech-/computer-savvy and needed her brother's help to switch on the computer, but from then onwards, her skills improved greatly: she could navigate the internet and was even writing on a manga story in a fan forum online. Communication about the media, and forms of mediation, happened within the family throughout the study, while the parents did their best to inform their children about possible dangers, or they discussed interesting content together. All in all, Elisabeth's parents could be said to have shown a sort of child-centred mediation (see Chapter 7).

Despite the limited options for actions, all members of the family were able to direct their outlines for actions towards the family. As a result, the climate of relationships within it was intact and very stable throughout the years, providing a good basis for Elisabeth and her brother to cope with their developmental tasks and to develop their own competences for action. We consider that Mr. and Mrs. Ebner tried to be role models for their children and to guide them as they grew up, while at the same time leaving them their free space to explore their options. For the Ebners, an open form of communication was clearly the key to their parenting strategy. As a result, we always observed that Elisabeth did very well in her 
life, with strong ties to her family, a solid circle of friends and training to become a florist, a profession she had been dreaming about for a long time. At the end of the study, Elisabeth seemed fairly capable of developing her own outlines for actions, as well as being well able to shape her future life for herself.

\subsubsection{The Kaiser Family}

The Kaiser family consisted of Mrs. Kaiser-a single mother after the divorce from her husband between the third and the fourth waves-her son, Torsten, and his two younger brothers. She was working part-time before she developed psychological problems during the sixth wave. She had, in fact, already had a long period of hospital treatment during the fifth wave. Mrs. Kaiser still lived in the owner-occupied flat that she and her ex-husband had bought together and was, by and large, satisfied with her living situation.

Her ex-husband remarried after their divorce and fathered a daughter. In contrast to other families of this type, the contact between Mr. Kaiser and his children, as well as his ex-wife, remained fairly good. Torsten was especially close to him and loved his half-sister dearly. His important reference persons were his grandparents, who offered him much support. Conflicts between Mrs. Kaiser and Torsten occurred during the fifth wave, when Torsten was trying to gain more independence. His mother always remained anxious to maintain a good relationship with her kids, even when her mental health issues began. From the beginning of the study, through the divorce and until the end, the family was always able to solve problems together very competently, and the family ties remained strong. Yet Mrs. Kaiser and her younger children experienced Torsten's moving out as a welcome relief, because the apartment had become very crowded as the children grew older. Torsten was able to get into job training, and because of limited space at home, he had to live in a hostel during the week. This was something Torsten actually experienced as a relief.

The family had always been very well-equipped with media, and Torsten himself had been an avid media user for some time. His mother, therefore, monitored her son relatively strictly, but not methodically, whereas his father allowed him to play undeniably violent computer games. During the third and fourth waves, his mother said that he would watch television or play video games all day long if 
allowed to. During the sixth wave, after moving out during the week to stay at his employer's hostel, he did not have to stick to his mother's rules anymore and seemed to spend most of his leisure time with media. At the same time, he occasionally misplaced his phone, not finding it for days. Yet he seemed critical in his media use, was interested in media production, knew a lot about privacy settings on social media and had only 23 friends on it, mostly close friends and family, when the study ended.

Mrs. Kaiser tried to keep an open relationship with her children, in the hope they would not keep secrets from her. These attempts met some resistance, when Torsten started to play online video games intensively and was spending his whole leisure time with game playing. In order to minimise the potential risks to her son, she installed a filter software without informing him about it, meaning she had decided to enforce a particular restriction (see Chapter 7). In general, the climate in the family remained very good, as Torsten, despite conflicts with his mother, lovingly looked after his younger brothers and cared about them. His mother supported him, and, as he grew out of puberty, Torsten did seem to rely on her and to realise that his mother cared about him.

Despite their limited options for actions, the Kaiser family was able to cope with their everyday life and its various challenges in a very competent way through mutual support and communication.

\subsection{The Families of Type 4}

Families in Socio-Economic Circumstances No Longer Strained and with Unproblematic Socio-Emotional Relationship Structures: The Competent Social Climbers. (Grubert, Scheib, Pfortner, Dornbacher and Zarbl)

Type 4 consists mostly of families who had been living together in the same constellation for some time during the study. These families can be described as "social climbers" because they experienced a significant improvement in their socio-economic situation for various reasons, like marriage, new jobs, an additional income or a pay raise. Some of the families already had a good and solid socio-emotional relationship structure at the beginning, while others experienced a considerable improvement, often as a result of better socio-economic circumstances. All the families made a stable and solid impression by the end of the study and 
were able to cope with everyday life challenges quite competently. Once having moved up socially, the families were eager to secure their position and to stabilise the situation for themselves. Since they did not want to endanger their new status, their outlines for actions were focused on maintaining the good climate among them, in order to also secure the improved situation for their children.

The parents of the Type 4 families were characterised by a very devoted attitude towards their children and their needs, as well as interacting respectfully with them. After they largely shed the burden of financial troubles, these parents were able to focus their attention on their children rather than on finances, health issues, broken relationships or unattainable outlines for actions. Through their improved resources (of money as well as time), these parents had more leeway in raising their children in greater comfort and closer relationships. Parenting strategies based on child-centred mediation rather than unmethodical restriction gave the children freedom to develop their individual "EigenSinn" (selfwill). This became obvious in the outlines for actions and the acquisition of competences for action, like more self-esteem and clearer goals in pursuing their own professional career paths.

\subsubsection{The Case of Erich Grubert and His Family}

\subsubsection{Situation and Climate of Relationships Within the Family}

When the study began, Erich (17 years old in 2016) and his single mother were living in a fairly deprived neighbourhood. Ms. Grubert was reluctant to let her son play outside and avoided contact with other residents and children. As a result, Erich spent most of his leisure time inside their apartment and used the media to relieve his boredom. $\mathrm{He}$ was slightly obese, hyperactive and could not concentrate on anything.

The situation of the family improved, however, when Ms. Grubert was able to increase her working hours and, in addition, find a new partner during the second wave. A newly-formed family resulted and moved to a bigger apartment in a nicer neighbourhood, remaining in this constellation until the end of the study.

These events marked a significant change in the life of the family. From then on, they experienced much more stability and were able to gradually improve their overall situation, financially level as well as regards relationships. The changes also affected Erich, whose small social circle began to widen, as his mother no longer had reservations 
regarding the neighbours' children. Over the years, Erich's health also improved, with any problems slowly subsiding.

Although Erich and his stepfather did not share many interests at the beginning, and the stepfather's ideas of masculinity and leisure time activities were not always in line with Erich's, the boy accepted him in his father role. They had a fairly good relationship, sometimes even sharing an interest in repairing motorcycles together. For these reasons, we proceed by referring to Ms. Grubert and her new partner as "parents".

Throughout the study, there was hardly any doubt that Erich had a close relationship with his mother. Her statements and his statements usually matched, with the exception of smaller secrets, like his first girlfriend, which Erich kept from her as he grew older, apparently not yet being willing to share them. But Erich never left any doubt about how important his family was to him. Even as a teenager, he said that he would take them with him to a desert island, while the importance of his family is underlined in his network map, where his family is drawn very close to him (see Fig. 8.7).

The financial situation of the family improved still further between the fourth and fifth waves. Ms. Grubert's partner, an IT technician, got a new job with a new employer, which meant a higher income and no more night shifts. This left him more leisure time to spend with

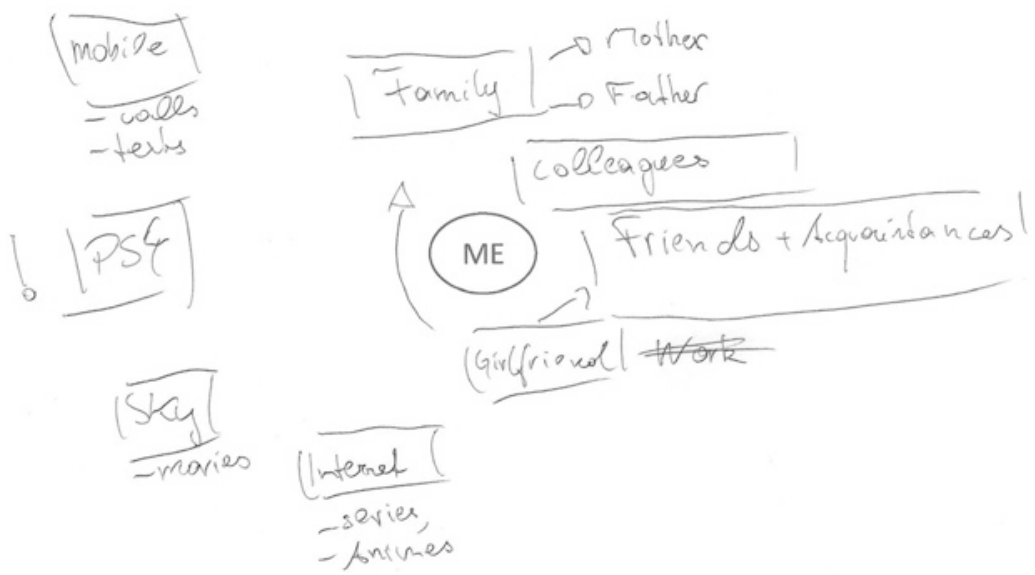

Fig. 8.7 Network map by Erich Grubert in 2016 (Tracing based on the original, translated and anonymised by the authors) 
the family. Erich had also started job training to become a cook, which he enjoyed a lot, not least because he was now earning his first salary. He said that he enjoyed the concomitant freedom and independence. He offered to contribute a part of his salary to pay the rent, but his mother declined it.

This big step in Erich's life also had an influence on his daily routine, his leisure time activities, his circle of friends and especially also on his media usage. He slowly replaced the previously important school friends by friends he made at work. As Erich himself attested, the time he spent together with his colleagues during and often after work too became more important for him, so that only one long-time friend, whom he had known since moving to the new neighbourhood, was still close to him. Along with new friends, a new girlfriend also claimed his attention and leisure time.

Working usually from noon until half-past-nine or ten in the evening and having few free weekends limited the time available for the previously dominant video games. Similarly, activities together with the family also became fewer, as did Erich's involvement with the boy scouts. Instead, Erich now enjoyed the occasional night out with colleagues or his girlfriend.

The only negative development Erich experienced during the last years of the study was the complete loss of contact with his biological father. Contact had never been good, but he did hear from his father, at least from time to time. To compensate, Erich found support from his stepfather and the latter's parents.

With a stable relationship network and a lot of mutual trust within the family, the Gruberts were always able to cope with problems and challenges competently. During the last year of school, Erich was struggling with the demands and the stress, which sometimes clouded relations, but he and his parents were usually able to resolve these issues together. By the end of the study, Erich has directed his outlines for actions towards finishing his job training and entering another programme to become a butcher, which would enhance his later job opportunities and his income.

The parents were content with their overall situation, especially since Erich's job contributed to a better climate in the family and an even closer relationship between them, after the stresses of school were over. They were considering a house in the suburbs, while Ms. Grubert was acquiring some unspecified further education. 


\subsubsection{Media}

As of the second wave, the family was always well-equipped with media, which can be attributed to the step-father's profession as an IT technician. The devices usually reflected state-of-the-art technology, although Erich's mother was the least interested among them in the latest models of smartphone or the like. Erich liked to update his media equipment, especially after beginning to earn his own money, when he started to buy additional devices. He was very proud of his favourite spot in his room, where he had his own flat screen TV, various consoles and a selection of video games.

The picture he took also shows Erich's hookah (an instrument for smoking flavoured tobacco, with origins in India that has become increasingly popular among young people in Austria in the last years), something that he was also very proud of. Brands were important to Erich when buying equipment. His parents declared that he was very selective and had a clear idea of what he wanted, where he wanted to obtain it, and where he could get the best price.

Erich's media-related interests did not change much throughout the study, but the intensity of his which media use changed over the years. During the first wave, his media usage was highly intensive due to a lack of other leisure time activities, so that the media served as a means to compensate for the limited social contacts with peers. Erich expressed an early interest in content focusing on natural science and fantasy. Anime, for example, remained a central interest of his throughout the study.

A decrease in Erich's media usage, following the changes he underwent between the first and second waves, lowered its intensity for some time, until video games gained importance between the fourth and fifth waves. By that time, the media had begun to serve as a release for school stress. They became a focal point during his youth and adolescence. During the third wave, Erich explained that his favourite object in his room was his PlayStation 3. He later acquired a PlayStation 4 (PS4), which was so important to him that he marked it with an exclamation mark in his network map from the last wave (see Fig. 8.7).

Erich's interest in video games gave him extensive knowledge of gaming vocabulary and strategies and a liking for complex and intricate games. He was familiar with cheats and managed to master the game, Skyrim, within just two weeks. This particular game had previously caused a conflict between Erich and his mother during the fourth wave, since Ms. Grubert did not approve of the game and refused to buy it for her son. Erich knew the game through one of his friends and, although he 
recognised that there was a lot of blood and violence in it, he claimed that he only wanted to play it for the storyline. When our interviewer asked whether he liked blood being everywhere, he responded: "No, actually I only play it because of the story, it's good quality, that's why I play it. I don't care, if it was up to me, it could be without the bloodshed at all!"

Playing complex video games presented a challenge for Erich and helped him experience self-efficacy. His mother assumed that he was suffering from low self-esteem after being mobbed in school because of his weight, so that being successful at video games restored some of his self-esteem.

Apart from anime and video games, the internet, social media, together with the smartphone as a device that bundles all these services, gained importance during the last two waves. Erich was mainly an observer and hardly ever active on platforms like Facebook. Unlike other children in the sample, he had only about 80 friends, but knew all of them personally.

Once Erich started his job training, he had less time for media, so the intensity of use reduced, and Erich's parents claimed that he became much more responsible with the media. He used his smartphone less in the end, since it was forbidden at his workplace, which influenced his media usage in another way as well: Erich began listening to the radio a lot, as it was always on in the restaurant kitchen. It became his most important source of information, especially during the refugee crisis in $2015 / 2016$.

The Gruberts' family activities also included using the media together throughout the study. Usually the television had been the focus of their media usage in common, as when watching crime series together. This activity had declined due to Erich's new daily routine, but the occasional television evening together still took place.

Overall, media were very important to the Grubert family. Due to the stepfather's profession, the media also had a high practical value, given that the family's income was mostly based on working with them. The media were constant companions and were used in many different ways for entertainment and for convenience in sourcing information. As Erich's mother pointed out in the last interview, they could not imagine life without them.

Information about, for example, sport events played a crucial role. Particularly notable throughout the study was the family's large collection of books, in addition to the various electronic devices. 
Ms. Grubert collected various books about pets and animals in general, and used them as sources for advice on the family's number of pets throughout the years (cats, snakes, a dog, a hamster).

Nevertheless, the generally positive attitude towards the media did not mean that all content was viewed uncritically by Erich's parents. Ms. Grubert did not care for violence and pornography, as in her refusal to buy Skyrim for Erich, but she said that she later gave in because in her opinion refusing would ultimately only make it more desirable to him.

\subsubsection{Parenting and Role of Socialisation Contexts}

The parenting strategies in the Grubert family were mostly based on a form of child-centred mediation, especially with regard to media literacy. The expert in the family was Erich's stepfather, at least as far as the technological aspects of media usage went. He was the one with an eye to filter software, who took care to teach Erich an awareness of privacy issues. Talking about media content or issues related to the potential risks of media usage had been happening from the second wave on. As a result, Erich appeared to be a fairly aware media user.

At the beginning of the study, Ms. Grubert told us that she strictly controlled her son's media usage, but the details of her actual practices indicated that these actually tended to laissez-faire. She often emphasised later on that she did not approve of punishment or restrictions as educational tools, but, if anything, she used praise as an incentive for the "right" behaviour. She put a lot of trust into her son and in his ability to tell right from wrong.

In Erich's case, the crucial role of a family's dynamics for the development of a child became very clear. His youth was marked by two fundamental changes, with far-reaching effects on his family's situation and on himself. The first big change was his mother's new partner, who slowly became accepted as a father figure. The relationship with his mother endured, and thus Erich experienced a form of stability and support that he was lacking when the study began. Although the interests of stepfather and stepson didn't always match, Erich gained new and different experiences and could also explore new possibilities for his leisure time.

The second big change occurred via Erich's job training, which had an impact on his daily routine, his social circle and also on his media usage. As opposed to school, which Erich sometimes experienced as a chaotic and restrictive socialisation context, his work provided opportunities for new outlines for actions. The new school that he attended as part of his 
training was much more to his liking, and he got better grades, had a good relationship with his teachers and actually enjoyed it overall.

Working together with people of different backgrounds and ethnicities seemed to broaden his horizon, causing him to talk about issues of immigrants and the refugee crisis in a very reflected and less negative way. $\mathrm{He}$ perceived the change of his social circle through the new school and the workplace as a positive development, because he had suffered from bullying in his old school, where brands and clothing were a big issue.

Concurrently with the job training, Erich's relationship with his parents had also changed. He still saw them as important reference bullying persons, but at the same time he enjoyed his growing independence and in turn, his parents respected their son's maturing, not seeing themselves as educators anymore. Ms. Grubert felt that the time of actual "parenting" was over, and that they were more supporters and encouragers.

\subsubsection{The Other Families of Type 4}

\subsubsection{The Scheib Family}

Much like the Grubert family, the Scheib family was in a very precarious situation when the study began. Mrs. Scheib was a single mother with two daughters, and the family lived in a very small, crowded apartment. She and her daughters had to make ends meet with what she earned from working 15 hours a week and received in alimony payments. Their situation changed radically when Mrs. Scheib met her prospective husband between the first and second waves. They moved to a large city in the south of Germany and into a bigger apartment in a very nice neighbourhood. As a consequence, Mrs. Scheib and her daughters experienced a massive increase in their options for actions, especially since the opportunities for the children in the neat, affluent surroundings, together with their better financial situation meant new possibilities for shaping their leisure time activities.

Susanne, the older of the two siblings, at first struggled with the move, because she had to leave all her friends from kindergarten behind. Among other things, she tried to use the media to compensate, but she was able to make new friends as well, which reduced the relevance of the media. Throughout the study, Susanne and her sister were in touch with their biological father back in Austria, and that also enabled her to stay in touch with other relatives in her old home-town. The only person 
Susanne did not get along with was the father's new girlfriend, whom he had met before the sixth wave, but his daughter's relationship with him seemed not to suffer from this.

After these life-changing events, Susanne's situation was marked by stability, and her stepfather became an important person of reference for her. Her mother remained a central reference person as well, with their relationship seeming fairly balanced and trusting, but it was somewhat shaken when Susanne apparently suffered a personal crisis shortly before the sixth wave. She quit school, although previous interviews had always shown her to be a good student with very good grades, who liked going to school. Puberty and the developmental tasks linked to it apparently put a strain on her, which was expressed in a sudden and strong wish for independence. In the last interview, Susanne mentioned that her views and her parents' views had drifted apart by that time. She turned to an intensive use of the media, and her mother reported about up to seven hours of watching television a day. The media had gained much relevance overall, with, in particular, her smartphone becoming a focal point of her media use, especially for managing contacts and using social media. Prior to this, Susanne always displayed a very moderate use of the media, and they had played more of a subordinate role in her life between the first and fourth waves. Mrs. Scheib presented herself as rather critical of the media (and especially the mainstream media) and saw risks, but she also emphasised the benefits of the media use at various points. However, the family's range of media devices was comparatively small, especially when the study began.

When the study ended, Susanne was 18 years old and appeared to have overcome her crisis. She caught up on her school education and was aiming to earn her secondary school certificate and to continue to a higher secondary vocational school. In the meantime, the television had lost its relevance almost completely, while only the smartphone remained important for managing social contacts. As an almost grown-up, Susanne was now focusing more on her friends and considered them to be a very important part of her life.

Susanne and her family have always been competent at dealing with everyday life challenges - a central characteristic of the Type 4 familiesand so they were also able to resolve Susanne's crisis and to help her find her own way to future independence. 


\subsubsection{The Pfortner Family}

In contrast to the Scheib and Grubert families, the Pfortners' economic situation did not improve because of a new partner, but because of an increase in the parents' financial resources. This led to better options for actions for the family, consisting of the son, Helmut, a daughter older than him, Mrs. Pfortner and her husband, the father of both children. The family had been living in a house adjacent to Mr. Pfortner's workshop. On its own, the father's business was not doing well enough to support the family adequately, and between the second and third waves, Mrs. Pfortner took up another part-time job outside of the family business. This led to an improvement in the overall situation. Slowly but steadily, the business seems to have done slightly better as well, but the income continued to fluctuate, so Mr. Pfortner was thinking about expanding to make more money. By the end of the study, the family was able to renovate and extend the upper storey of the house, with an apartment for each of the children. The previously precarious and rather insecure financial situation had improved a lot over the years, and had actually disappeared by the end of the study. Helmut had suffered from their strained circumstances at the beginning, but his situation also improved along with the family's fortunes. He was even able to catch up on his school education, after being diagnosed with a limited degree of ability at the beginning of the study and having to stay in kindergarten for another year.

The socio-emotional circumstances in the family were mostly very stable throughout the study. Helmut has always had a close relationship with his father, who was hoping that his son would take over the family business at some point. Helmut was especially close to his mother in a supportive and trusting relationship, which persisted as Helmut grew older. He confided in her when he had problems, helped her out wherever he could and talked about what was going on in his life. The wider family ties appeared very strong, with his relationship to the older sister being very good, as was his contact with other relatives, like grandparents, and particularly with one aunt.

There was one conflict that shook the family during the fourth wave. It involved a fight between the parents resulting from an incident with alcohol (which was not further elaborated on). Helmut's aunt was able to mediate in this dispute, and after it was resolved, there was no more mention of conflicts or alcohol-related problems, so it was presumably a one-time incident. 
Despite his very close relationship with his whole family, Helmut started to develop a more independent life towards the end of the study and began to focus on his friends and his sporting activities-Helmut has been an active wrestler for many years and is one of only few children in the panel who participated in an organised sports club activity-so that his training and competitions took up most of his leisure time. By the end of the study, he also mentions a girlfriend, who equally required a lot of attention.

Helmut was able to enter job training to become a machine-tool technician and was, thus, on track to follow in his father's footsteps. Mrs. Pfortner was very proud of her son's development and emphasised how mature, independent and autonomous her son had become.

Throughout the study, Helmut had always been a rather intensive media user, especially at the beginning, when he used the television a lot, but the focus of his media use shifted as he grew older. Especially the smartphone became more and more relevant, mostly to communicate with peers. He started to choose the media content he was using more deliberately as well and, because of his job training and his sporting activities, he did not have much time left to use the media in his leisure time. Mrs. Pfortner was very happy about this development, as she has always been critical of his media use, although she considered the media in general important.

The stability that his family provided was clearly reinforced by more financial security, and, in turn, contributed to Helmut's development. The family had always been competent at dealing with every day-life challenges and found ways to cope with problems together.

\subsubsection{The Dornbacher Family}

The situation of the Dornbacher family, consisting of Mr. and Mrs. Dornbacher and their two daughters, had been greatly influenced by changing employment in the course of the study. The family only displayed a few specific characteristics of a social disadvantage because they were living in an owner-occupied apartment in the countryside and expected to pay it off in a few years. However, the financial situation was difficult when Mr. Dornbacher was on parental leave and his wife was working 15 hours a week in an office. The father changed jobs frequently in the years following his paternity leave, and their situation was sometimes more, sometimes less strained, as was the climate among them. But throughout the years and all the developments, the parents 
always made sure that they supported their children by inculcating a feeling of support and security. The fourth wave saw a big change for the family, when Mr. Dornbacher was able to get a fairly well-paid, full-time job nearby and the financial situation became notably better.

The relationship between the parents and the children could be best described as amicable, the father was a good interlocutor, especially for his daughter, Gudrun, and they would often discuss books in general, as well as philosophy. The harmonious situation also large to other relatives. Gudrun and her sister were very close to their grandparents and their various aunts and uncles. Parenting was mostly based on child-centred mediation and had a strong focus on furthering the children, no matter what the financial situation looked like.

The improved financial situation, and the better options for actions related to it, became visible in Gudrun's outlines for actions after the fourth wave-she was able to visit a private Montessori secondary school and was focusing on passing the admission test for the academy of music to study the flute (recorder/English flute) and become a music teacher. Music had been a hobby of hers for a long time, and her parents always did their best to support her in this endeavour. Like many other children in the panel, Gudrun liked watching television-especially during a period in the fourth panel wave when she had had trouble finding friends and so had used media content for orientation and coming to terms with topics that preoccupied her. Later, the smartphone became more important, but Gudrun had been an avid reader as well and actively wrote stories herself, even publishing some of them online. Her passion for books was also something that stood out in the panel and was something that her parents had passed on to her, being avid readers themselves. Her creativity and her ability to express herself were mirrored in Gudrun's network maps, which were always very elaborate. Her network map from 2014 shows how much thought she put into arranging the people who were important to her in carefully designated circles around her, thus visualising the proximity (see Fig. 8.8).

The map displays many friends, both boys and girls, some of whom had been her close friends for years (e.g., since primary school), as well as her close relatives, with whom she shares her inner circle.

\subsubsection{The Zarbl Family}

Similar to the Scheib family, the Zarbl family experienced a social elevation when Mrs. Zarbl acquired a new partner and later married him. In 


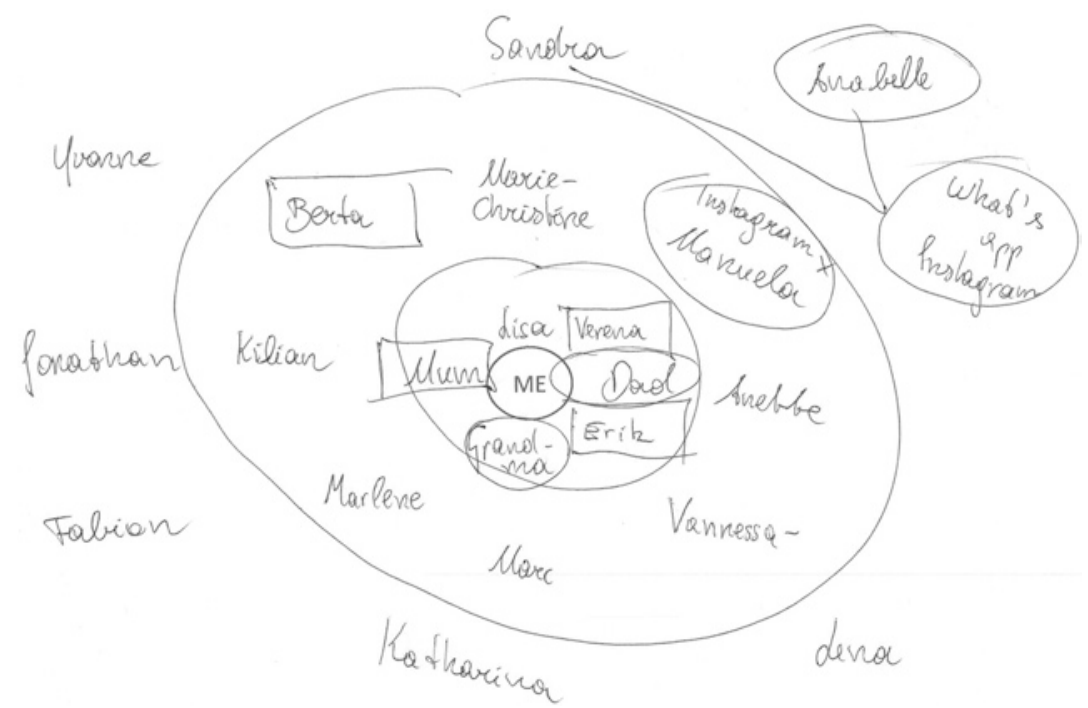

Fig. 8.8 Network map by Gudrun Dornbacher in 2014 (Tracing based on the original, translated and anonymised by the authors)

the first wave, the family still consisted of Mrs. Zarbl, her son, Norbert, his younger brother and the biological father of the two boys. The climate in the family was very strained at that time due to the parents' conflicted relationship. As a result, the relationship between Norbert and his mother was problematic. Norbert was watching a lot of television, but rather aimlessly, while his parents often used television as a "babysitter" to keep him occupied while they were struggling with their stressful relationship and overall situation. Mrs. Zarbl and her partner separated before the second wave, leaving Mrs. Zarbl short of money. However, the family's socio-emotional circumstances improved, with regard to the ex-partner too, as the separation had taken a lot of pressure off both parents. By the third wave, Mrs. Zarbl had a new partner, who brought financial stability back into the family. Subsequently, Mrs. Zarbl increased her working hours, which contributed to the further improvement of the socio-economic situation and its increasing stability. Norbert and his biological father kept in touch throughout the study, although, due to time constraints, contact reduced when Norbert started his job training. His stepfather became an important reference person as well. 
Mrs. Zarbl's new partner and husband brought two kids of his own into the family, but they were already grown-up and independent and, thus, did not move in along with him. We registered only minor conflicts, one of which was, in fact, media related, when, during the fourth wave, Norbert's biological father and his stepfather differed about the action movies Norbert was not allowed to watch at home, but which his father allowed him to watch at his place. Mrs. Zarbl tried to control Norbert's media usage- to his annoyance-but she could not manage this consistently. Apart from that, Norbert's relationship with his mother improved tremendously during the study and became much more balanced. But Norbert continued to be generally introverted, although, as he grew older, he started to be more independent and spend more and more time with his friends. Communication with his friends was a priority, which is why his smartphone was so relevant to him. He also continued to like various video games, like Call-of-Duty. Norbert had very elaborate media equipment in his room, clearly designed to make the most of his gaming experience, as a picture of his favourite spot for media use shows that he took in 2014: A centrally arranged flat screen TV is framed with a powerful sound system, different game consoles, receiver and a stereo system are at Norbert's disposal.

When the study ended, Norbert seemed fairly competent at managing his life and future perspectives, something that he learned from his mother and his family, both parties proving to be fairly competent at dealing with life challenges over the years of the study.

\subsection{Conclusion}

The typology presented in this chapter clearly demonstrates that children and their families operate within an individual framework, where the family develops ways of coping or fails to cope. This chapter helps to understand how many of the researched families, especially from Type 1 and Type 2, were often overstrained in multiple ways and experienced different forms of deprivation on many levels. The families differ greatly from each other as far as their options for action, their outlines for action and their competences for action are concerned.

While the Type 1 families suffer from severe socio-economic problems, experienced as multiple deprivation-they are overall rather overwhelmed by their situation/unable to cope-the Type 2 families do not experience socio-economic problems anymore or only to a very small 
extent compared to the beginning of the study in 2005, but their situation is very strained because of severe problems on the socio-emotional level that did not resolve when the financial situation improved-especially with regard to the relationships between parents and children. As a consequence, the Type 1 families are characterised by very limited options for actions, especially on the parents' part, since the socio-economic resources are very scarce and the worry about making ends meet overshadows the families' everyday life. Many of the parents and children belonging to this type began to develop health issues during the study, and these dominated the everyday life and the relationship structures within the families, burdening and problematising their doing family even more. In the light of the limited options for action, the outlines for action often appear limited as well, and everyday challenges-like supporting the family, buying clothes, parenting and so on-meet with a lack of competences for action. This constellation leads to a feeling of overextension; some even fail altogether at coping with their everyday challenges. All the children who experienced this particular constellation suffer from the conditions in the family and experience hardly any support, or none at all, in fulfilling their own developmental tasks. Depending on their cognitive abilities and their self-will, they were, like Timo Landinger, either not able to develop their own outlines for action and to build competences for action, or only to a limited extent, as Manfred Oblinger was doing by the time the study ended. What stands out about the Type 1 families is how they differ from those of Type 3 and Type 4 in a fundamental sense: having no security network among relatives or friends.

Among the adolescents, it was mainly the boys who had problems keeping up with peers in terms of their individual development, so that they often turned into mavericks at their schools. Either they had no friends or very few to share their interests. Their friendships were primarily based around their online games. Considering the fact that, as we pointed out in Chapter 3, there is a correlation between the relationships among family members, the ways in which family members interact with each other, and the children's ability to form relationships later in life, romantic as well as with peers, it is not surprising that the adolescents of Type 1 had not formed romantic relationships during the time of the study.

The situation of the Type 2 families is, as was already described, different in its interplay of options for action, outlines for action and 
competences for action, as applied to the individual family members. The options for action improved over the time of the study for all the families of this type-mostly single mothers at the beginning-through marriage, but also through inheritances. These families experienced increased financial resources, but their problematic socio-emotional relationship structures remained unimproved and they continued to have problems and struggle with overextension within the nuclear family right up to the end of the study. The mothers of this type were often disinterested in their children and left them mostly to fend for themselves, something also mirrored in their parenting strategies and media education.

When they were no longer single, some mothers directed their outlines for action fully towards their new partners and new children and used their competences for actions to tackle challenges that they met there, whereas the "old" children became less relevant, to the disadvantage of the latter. Usually, they received hardly any support from their family with their own developmental tasks and did not feel at home in their own families. Benedikt Holzner is a very special case in this context, as we showed, since he was able to overcome the traumatic experiences from his early childhood and his mother's disinterest and neglect through moving into an assisted-living facility, where he was able to develop resilience and independence.

The Type 3 families show entirely different characteristics again. They are faced with socio-economic problems, but their socio-emotional situation is quite stable and their relationships among family members are fairly strong, which helps them to better cope with challenging everyday situations. These families experienced deprivation on the socioeconomic level from beginning right up to the end of the study, limiting their options for action massively (similar to the Type 1 families); but, in contrast to those from Type 1, the parents (mostly single mothers), directed a great deal of their energy, their outlines for action and their competence $s$ for action towards securing a harmonious family life, as is obvious from their approach to parenting They practised mediation, communication and trust, even though they could not always manage this consistently. These parents supported their children in dealing with their developmental tasks as best as they could under the given circumstances and within the restrictions of the socio-economic situation, so that the children appeared fairly competent at mastering their own lives by the time the study ended. 
Lastly, we presented the Type 4 families, who can be characterised as "the social climbers", since they experienced an improving socio-economic situation throughout the study and did not show any problems on the socio-emotional level (anymore) either. The improvement happened through new and/or better jobs or more work hours and new partnerships. Their options for action improved along with the increasing financial resources. These families were mostly fairly stable at the beginning, but the socio-economic improvement further contributed to stabilising them. Their children profit from the increasing resources and the growing stability, since they experience a lot of support from their parents, whose outlines for action are clearly directed towards the children, helping them in their development and enabling them to develop their own outlines for action and acquire the necessary competences to realise them. It is evident that the children profit from this support network in their socialisation. The doing family and the parenting in these families is again marked by child-centred mediation and a much less laissez-faire approach or an unmethodical, restrictive one, as compared to the families of Types 1 and 2 .

Based on the presented results, it can be established that the socio-economic frame does shape everyday life of the families, but the socio-emotional circumstances in the nuclear relationship structures are decisive when it comes to coping with everyday challenges.

The individual interplay of options for action, outlines for action and competences for action of the parents in particular, but also of the children as they grow older, form the foundation of the actual everyday life in a family, as well as their doing family. It also shapes how successful the children were in dealing with and using media in the process of their socialisation. Although it is not possible to infer a typology of media usage, it becomes clear against the background of the presented data, that media usage and what is often deemed a "bad" form of media usage can become symptomatic for other things going wrong in a child's life. In this context, an interesting finding is that the adolescents of Type 4, but also of Type 3, value face-to-face-relationships as more than mediated recreational time. They do indeed use computer games and are interested in other (media-related) activities, but these are not a basis determining their recreational time. Instead, it is the immediate contact with friends that is by far more important to them.

With regard to media usage or patterns of media use, it became clear that we could not identify type-specific patterns of media usage, 
especially not to the extent that such patterns would have been stable across the types throughout the study. However, we could show that the overextension and inability to cope that some families, especially Type 1 and Type 2 families, experience, expand into all areas of everyday life, especially in the ways family members treat each other, interact with each other, in how parents are willing and able to pay attention to the needs of their children and to help them come to terms with their lives. This circumstance even expands to and influences the ways in which children broadly use the media, how they handle media technology and how media literacy is mediated within the family. Some of the families, who experienced an improvement of their situation (economically or emotionally, or both), often mirror this in their stronger orientation towards their children and a more devoted attitude towards parenting, which again is also mirrored in their mediation strategies regarding media literacy, as we were able to show in Chapter 7.

In conclusion, we can say that the typology presented in this chapter draws attention to how the dynamics, both with and without the media, of family life and socialisation develop. The typology can be understood as a step-and one underpinned empirically by our research-towards a better understanding of how to systematically help families find (better) ways of coping and, regarding the use of media, develop specific media literacy concepts in order to enable a participatory response in children.

\section{Notes}

1. The original data is in German, all direct quotes that are used in this chapter were translated into English by the authors. In order to make the text more reader-friendly we did not include such a reference for the individual quotes.

2. Large families are defined as families with three or more children (Statistik Austria, 2017, p. 3); since larger families are particularly at risk of poverty, we were specifically looking for families with more than three children.

3. In order to illustrate the children's network map in an international context we decided to create a new version that keeps the style of writing, the visual elements. The terms that have been mentioned were translated and positioned at the same place as in the original map. Spelling mistakes in the original version are indicated by analogue mistakes.

4. Due to copyright reasons the pictures taken by the adolescents cannot be printed. They include visible third-party content like, for example, brands, logos and game visuals. Therefore, the text offers a description to better understand the settings instead of showing the pictures. 


\section{REFERENCES}

Havighurst, R. J. (1972). Developmental tasks and education (3rd ed.). New York, NY: McKay.

Kluge, S. (2000). Empirisch begründete Typenbildung in der qualitativen Sozialforschung [Empirically based typification in qualitative social research]. Forum: Qualitative Social Research/Qualitative Sozialforschung, I(1). Retrieved from http://www.qualitative-research.net/index.php/fqs/article/view/1124.

Paus-Hasebrink, I., \& Kulterer, J. (2014). Praxeologische Mediensozialisationsforschung. Langzeitstudie zu sozial benachteiligten Heranwachsenden [Praxeological media socialisation research: A longitudinal study regarding socially disadvantaged adolescents]. Assisted by P. Sinner. Baden-Baden, Germany: Nomos.

Statistik Austria. (2017). Statistics Brief Armut [Poverty]. Wien, Austria: Statistik Austria. Retrieved from http://www.statistik-austria.at/wcm/ idc/idcplg?IdcService=GET_PDF_FILE \&RevisionSelectionMethod= LatestReleased\&dDocName $=114988$.

Open Access This chapter is licensed under the terms of the Creative Commons Attribution 4.0 International License (http://creativecommons.org/licenses/ by $/ 4.0 /$ ), which permits use, sharing, adaptation, distribution and reproduction in any medium or format, as long as you give appropriate credit to the original author(s) and the source, provide a link to the Creative Commons licence and indicate if changes were made.

The images or other third party material in this chapter are included in the chapter's Creative Commons licence, unless indicated otherwise in a credit line to the material. If material is not included in the chapter's Creative Commons licence and your intended use is not permitted by statutory regulation or exceeds the permitted use, you will need to obtain permission directly from the copyright holder.

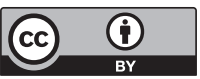

